\title{
Comparative mapping in the Fagaceae and beyond with EST-SSRs
}

\author{
Catherine Bodénès ${ }^{1,2^{*}}$, Emilie Chancerel ${ }^{1,2}$, Oliver Gailing ${ }^{3,11}$, Giovanni G Vendramin ${ }^{4}$, Francesca Bagnoli ${ }^{5}$, \\ Jerome Durand ${ }^{1,2}$, Pablo G Goicoechea ${ }^{6}$, Carolina Soliani ${ }^{7}$, Fiorella Villani ${ }^{8}$, Claudia Mattioni ${ }^{8}$, Hans Peter Koelewijn ${ }^{9}$, \\ Florent Murat ${ }^{10}$, Jerome Salse ${ }^{10}$, Guy Roussel ${ }^{1,2}$, Christophe Boury ${ }^{1,2}$, Florian Alberto ${ }^{1,2}$, Antoine Kremer ${ }^{1,2}$ \\ and Christophe Plomion ${ }^{1,2}$
}

\begin{abstract}
Background: Genetic markers and linkage mapping are basic prerequisites for comparative genetic analyses, QTL detection and map-based cloning. A large number of mapping populations have been developed for oak, but few gene-based markers are available for constructing integrated genetic linkage maps and comparing gene order and QTL location across related species.

Results: We developed a set of 573 expressed sequence tag-derived simple sequence repeats (EST-SSRs) and located 397 markers (EST-SSRs and genomic SSRs) on the 12 oak chromosomes $(2 n=2 x=24)$ on the basis of Mendelian segregation patterns in 5 full-sib mapping pedigrees of two species: Quercus robur (pedunculate oak) and Quercus petraea (sessile oak). Consensus maps for the two species were constructed and aligned. They showed a high degree of macrosynteny between these two sympatric European oaks. We assessed the transferability of EST-SSRs to other Fagaceae genera and a subset of these markers was mapped in Castanea sativa, the European chestnut. Reasonably high levels of macrosynteny were observed between oak and chestnut. We also obtained diversity statistics for a subset of EST-SSRs, to support further population genetic analyses with gene-based markers. Finally, based on the orthologous relationships between the oak, Arabidopsis, grape, poplar, Medicago, and soybean genomes and the paralogous relationships between the 12 oak chromosomes, we propose an evolutionary scenario of the 12 oak chromosomes from the eudicot ancestral karyotype.

Conclusions: This study provides map locations for a large set of EST-SSRs in two oak species of recognized biological importance in natural ecosystems. This first step toward the construction of a gene-based linkage map will facilitate the assignment of future genome scaffolds to pseudo-chromosomes. This study also provides an indication of the potential utility of new gene-based markers for population genetics and comparative mapping within and beyond the Fagaceae.
\end{abstract}

\section{Background}

Genetic linkage maps constitute an ideal framework for studies of the genetic architecture of quantitative traits $[1,2]$ and genome evolution [3,4]. They are also a prerequisite for map-based gene cloning [5-7] and for the ordering of physical scaffolds in genome sequencing projects [8]. Furthermore they are essential tools for marker assisted plant breeding [9].

\footnotetext{
*Correspondence: bodenes@pierroton.inra.fr

'INRA, UMR1202 BIOGECO, Cestas F-33610, France

¿Université de Bordeaux, UMR1202 BIOGECO, Cestas F-33610, France

Full list of author information is available at the end of the article
}

Comparative analyses of genetic maps across phylogenetically related species are based on the development of transferable and orthologous genetic makers. Simple sequence repeats (SSRs) are the markers of choice, because they are reproducible, abundant in the genome and they provide highly polymorphic information and are readily transferable between phylogenetically related species [10]. Their properties are highly prevalent in EST-derived SSRs, making these markers particularly useful, as shown for Theobroma [11], Silena [12], Prunus [13], Dactylis [14] and Citrus [15]. SSRs are also easy to handle and, once developed, are cost-effective markers for high-throughput genotyping.

\section{Biomed Central}

(c) 2012 Bodenes et al.; licensee BioMed Central Ltd. This is an Open Access article distributed under the terms of the Creative Commons Attribution License (http://creativecommons.org/licenses/by/2.0), which permits unrestricted use, distribution, and reproduction in any medium, provided the original work is properly cited. 
In the last 12 years, several linkage maps have been generated for the three main genera of the Fagaceae family: oaks (Quercus), beeches (Fagus), and chestnuts (Castanea). These long-lived species constitute important economic and ecological resources and have been the focus of genetic investigations relating to their evolution and more applied objectives, such as those of conservation and breeding programs [16]. Linkage maps have been established to support forward genetic approaches for studying the genetic architecture of adaptive traits (number, location and effect of QTLs) and to increase our knowledge of the structural features of the oak genome and its evolutionary history.

First-generation linkage maps have been obtained with anonymous RAPD and AFLP markers for oak [17], chestnut [18,19] and beech [20]. QTL studies, mostly in oak, have focused on dissecting the genetic architecture of adaptive traits, such as growth and bud phenology [21-23] and of traits related to species divergence between pedunculate and sessile oaks, two species occurring in sympatry in Europe [24,25]. A limited number of genomic SSRs (about 50) and ESTbased (about 50) markers [26,27], have also been added to these maps. These markers allowed to align homologous linkage groups between oak and chestnut and to compare and validate the QTLs that had been previously characterized in the two genera $[27,28]$. A first step toward the construction of a dense SSRbased genetic map was taken recently, with the development and mapping of 256 EST-SSRs [29]. The authors used a selective mapping strategy with a bin set of 14 highly informative offspring from a single full-sib (FS) mapping population for which an AFLP framework map was available. SSR markers were assigned to 44 bins of the female and 37 bins of the male parental maps, spanning the entire genome.

The main goal of this study was to advance the establishment of a dense EST-SSR-based map for oak, by genotyping trees with a broader genetic background and using a larger set of genomic and EST-SSRs. Our specific objectives were as follows:

i) To optimize comparative mapping between two Quercus species by identifying a subset of SSRs that were transferable and orthologous across different mapping pedigrees. We genotyped a total of 400 offspring from five families obtained from controlled crosses of the Q. robur and Q. petraea genotypes. We then generated 10 individual linkage maps (one for each of the parents used in the crosses) by the two-way pseudo-testcross mapping strategy [30] and constructed consensus maps for each species from 419 genomic and EST-based SSR markers. ii) To determine gene content (synteny) and order (collinearity) between these two sympatric species [7,30-32].

iii) To assess the transferability of a subset of EST-SSRs in several Fagaceae and Nothofagaeae species and to describe the genetic diversity of several oak populations depending on the type of the repeated motifs. We also mapped transferable EST-SSRs, in European chestnut for which two linkage maps were available [28] making it possible to refine the first comparative map for oak and chestnut [27].

iv) To unravel the evolutionary paleohistory of oak chromosomes, by genetic mapping of 321 EST-SSR and 60 SNP-based markers identified from oak transcriptome sequence information (31,798 Sangerbased unigenes from Ueno et al. [33]).

These four objectives are interconnected, as shown in Figure 1.

\section{Methods}

\section{Functional annotation of EST-SSRs}

The functional annotation of EST-SSRs was based on Gene Ontology [34] and was performed with Blast2GO [35], using the following parameters: Blastx search against the non redundant NCBI database (e-value of $1 \mathrm{e}^{-6}$ ).

On the basis of GO categories, we assigned oak ESTs containing SSR motifs (Ueno et al. [33]) to three principal groups: biological processes, cellular compounds and molecular functions. The GO classification obtained was compared (with Expander software, [36]) between four sets of sequences containing SSRs: 3'UTRs (7,680 elements), 5'UTRs (8,646 elements), coding regions (13,899 elements) and non-coding regions (15,829 elements).

\section{Mapping of SSRs in Q. robur and Q. petraea and construction of consensus species maps Mapping populations}

Five mapping pedigrees (P1-P5) of variable sample sizes were used (Table 1 ), consisting of one $Q$. robur $x$ Q. petraea, one $Q$. petraea and three $Q$. robur full-sib families. These full-sibs were installed at the nurseries of INRA (Cestas-France), the University of Göttingen (Germany) and Alterra (Wageningen -The Netherlands). DNA was extracted from the leaves with the DNeasy plant mini kit (Qiagen, Hilden, Germany), according to the manufacturer's instructions.

\section{Development of SSR markers and genotyping}

A subset of 573 EST-SSRs identified by Durand et al. [29] was screened for polymorphisms against the 10 parents of the five mapping populations and four offspring per pedigree. We added 93 genomic SSRs (gSSRs) described in previous studies [37-44], KawaharaT pers 


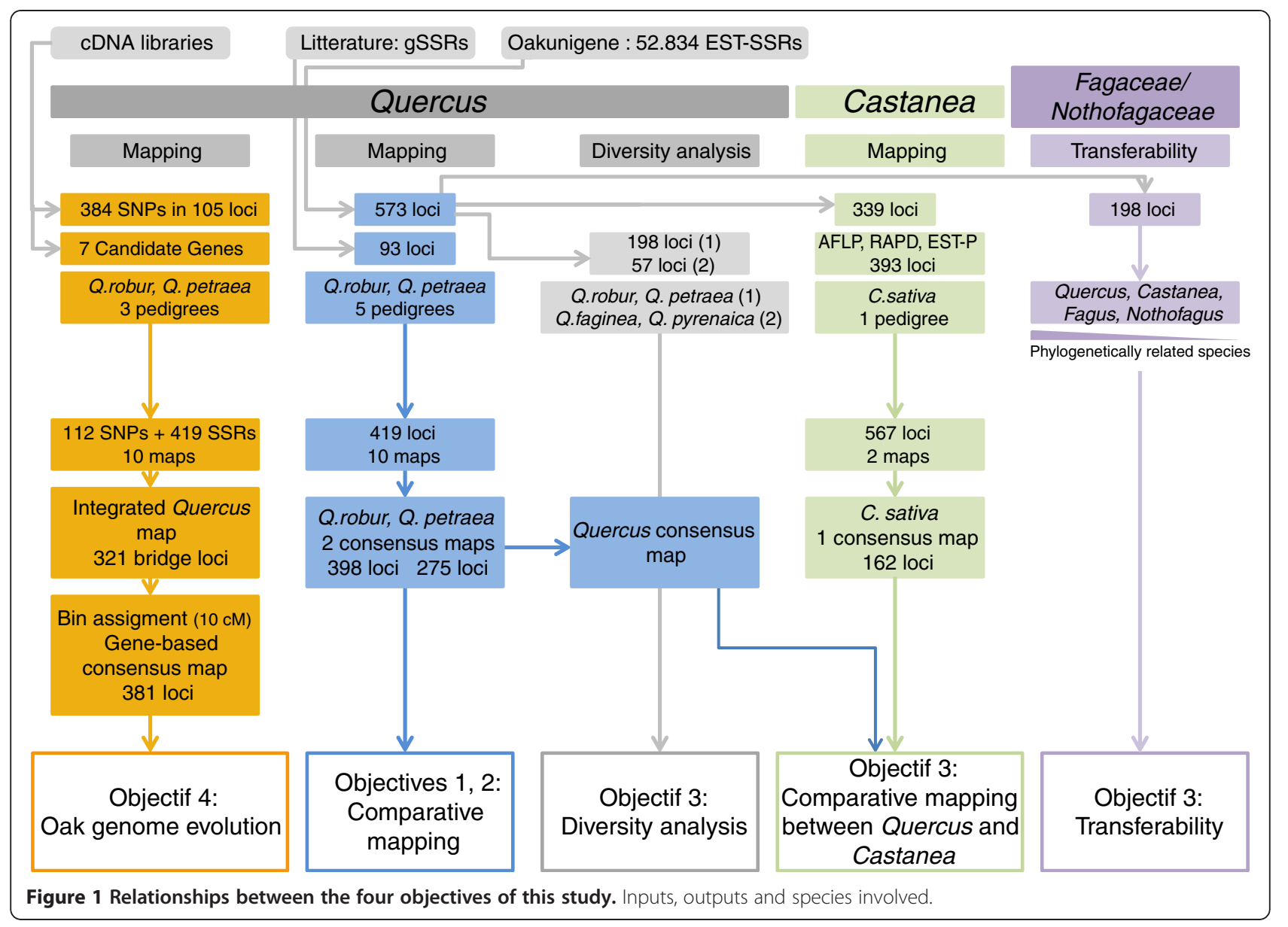

comm) to the screening step (see Additional file 1 for detailed information on markers and primer sequences). We then used the polymorphic markers to genotype the five mapping populations.

PCR amplification and fragment separation were optimized for M13 fluorescently labeled tailed primers [44]. PCR was performed in a final volume of $10 \mu \mathrm{L}$ containing $1 \mathrm{x}$ PCR buffer [10 mM Tris-HCl, $50 \mathrm{mM} \mathrm{KCl} 1.5 \mathrm{mM}$ $\mathrm{MgCl}_{2}, \mathrm{pH} 8.3$ at $25^{\circ} \mathrm{C}$ ] (BioLabs, Ipswich, England), $100 \mu \mathrm{M}$ of dNTPs, $0.045 \mu \mathrm{M}$ forward primers, $0.165 \mu \mathrm{M}$ reverse primer $(5 \mu \mathrm{M}), 0.165 \mu \mathrm{M}$ M13 primer, $0.25 \mathrm{U}$ of Taq polymerase (BioLabs) and 5 to $10 \mathrm{ng}$ of plant DNA. The cycling conditions were as described by Schuelke et al., [45]: initial denaturation at $94^{\circ} \mathrm{C}$ for 4 minutes, followed by 35 cycles of $94^{\circ} \mathrm{C}$ for $30 \mathrm{~s}, 56^{\circ} \mathrm{C}$ for $45 \mathrm{~s}$, and $72^{\circ} \mathrm{C}$ for $45 \mathrm{~s}$, nine touchdown cycles of $94^{\circ} \mathrm{C}$ for $30 \mathrm{~s}, 53^{\circ}$ $\mathrm{C}$ for $45 \mathrm{~s}$, and $72^{\circ} \mathrm{C}$ for $45 \mathrm{~s}$ and a final extension at $72^{\circ} \mathrm{C}$ for 10 minutes. Depending on the pedigree and partners, electrophoresis was performed with the Licor 4200 IR2 system (Lincoln, NB, USA), the ABI 3100 system (Applied Biosystems, Carlsbad, CA, USA) or the Megabace TM 100096 capillary electrophoresis system (GE Healthcare, Buckinghamshire, UK). The data generated were analyzed with the 4300 DNA analyzer software for the Licor system, GeneScan 3.7 and Genotyper 3.7 for ABI 3100 and Fragment profiler1.2 for Megabace.

Table 1 Description of the five full-sib mapping populations ( $N$ : sample size used for linkage mapping)

\begin{tabular}{lcllll}
\hline & Short name & \multicolumn{1}{c}{ Species } & N & Location & Country \\
\hline $3 P \times$ A4 & P1 & Q. robur $\times$ Q. robur & 92 & $44^{\circ} 44 \mathrm{~N}, 0.46^{\circ} \mathrm{W}$ & France \\
$11 \mathrm{P} \times$ QS29 & P2 & Q. robur $\times$ Q. petraea & 84 & $44^{\circ} 44 \mathrm{~N}, 0.46^{\circ} \mathrm{W}$ & France \\
QS21 $\times$ QS28 & P3 & Q. petraea $\times$ Q. petraea & 78 & $44^{\circ} 44 \mathrm{~N}, 0.46^{\circ} \mathrm{W}$ & France \\
SL03 x EF03 & P4 & Q. robur $\times$ Q. robur & 101 & $51^{\circ} 53^{\prime} \mathrm{N}, 9^{\circ} 93^{\prime} \mathrm{E}$ & Germany \\
AltP1 $\times$ AltP2 & P5 & Q. robur $\times$ Q. robur & 96 & $51^{\circ} 98^{\prime} \mathrm{N}, 5^{\circ} 66^{\prime} \mathrm{E}$ & The Netherlands \\
\hline
\end{tabular}




\section{Individual map construction}

We constructed 10 parental genetic linkage maps (7 for Q. robur and 3 for Q. petraea) by the two-way pseudotest cross mapping strategy [30]. Linkage analysis was performed with JoinMap version 4.0 [46]. Polymorphic SSR loci were classified into three categories: testcross markers segregating in a 1:1 ratio, testcross markers segregating in a 1:1:1:1 ratio and intercross markers segregating in a 1:2:1 ratio. Chi-squared goodness-of-fit tests were used to identify markers with patterns of segregation departing from Mendelian expectations. Loci with distorted ratios $(P$-value $<0.05)$ were excluded from linkage map construction. Individuals and loci for which more than $50 \%$ of the data were missing were excluded from the analysis. A minimum LOD score of 3 and a maximum recombination fraction of 0.45 were set as the linkage thresholds for marker grouping. Maternal and paternal datasets were created with the "create maternal and paternal population nodes" command in JoinMap. The regression mapping algorithm was used for map construction. Recombination frequencies were converted into map distances in centimorgans (cM), with the Kosambi mapping function. Linkage groups were drawn with MapChart [47].

\section{Estimation of genome size}

Genome length (L) was estimated from partial linkage data, according to the formula $L=n(n-1) d / k$, where $n$ is the number of framework markers, $d$ is the maximum distance between two adjacent markers (in $\mathrm{cM}$ ) at a minimum LOD score for linkage, and $\mathrm{k}$ is the number of marker pairs with a LOD value exceeding a minimum threshold [48,49]. LOD score thresholds of 3,4 and 5 were used to estimate genome length.

\section{Construction of consensus genetic linkage maps for $Q$. robur and $\mathrm{Q}$. petraea}

Consensus species maps for $Q$. robur and $Q$. petraea were established by combining parental map datasets for each species with the "join-combine groups for map integration" command of JoinMap, which creates a composite map from different linkage groups sharing common markers. We used the mapping parameters and options described above. We assessed the heterogeneity of recombination rates between SSR marker pairs, and SSR markers with highly heterogeneous recombination rates were excluded from the construction of species-specific framework maps. Markers that could not be ordered with the same degree of confidence were added as accessory markers, using the two-point LOD scores and recombination fraction available from the "maximum linkage" table of JoinMap. Similarly, when several markers were found to be collocated, only one was retained on the species framework map; the others were added as accessory markers.

\section{Databases}

Single-tree genotypic data for offspring and linkage maps are available from the QuercusMap database of the Quercus portal (https://w3.pierroton.inra.fr/QuercusPortal/index.php), the European genetic and genomic web resources for Quercus. DNA sequences and primer pairs for SSR loci are available from the SSR database at the same URL.

\section{Transferability of EST-SSRs and comparative mapping of oak and chestnut Transferability of EST-SSRs}

We assessed the transferability of EST-SSR markers to other Fagaceae species, by carrying out cross-species amplification in six species (Castanea sativa, Fagus sylvatica, Quercus faginea, Quercus pyrenaica, Quercus ilex, and Quercus suber). We also assessed transferability to two species of the related family Nothofagaceae (Nothofagus pumilio and Nothofagus antarctica). Each species was represented by at least two individuals. SSR amplification and genotyping were performed as described above, with a subset of 243 EST-SSRs randomly selected from the list reported by Durand et al. [29]. The selected microsatellite markers included 137 di-, 90 tri-, 2 tetra-, 1 penta- and 13 hexanucleotide repeats.

\section{Comparative mapping of Quercus and Castanea}

In total, 96 offspring of a single full-sib pedigree of Castanea sativa were genotyped with Quercus EST-SSRs. We assessed the amplification of 339 loci using the PCR conditions described above. Polymorphic SSRs were added to the polymorphic markers already available for this pedigree (including RAPD, AFLP, gSSR, EST-P markers; 393 loci in total). Individual parental maps and a consensus map were constructed with JoinMap, using the same procedure followed for Quercus. Finally, homologous linkage groups in Quercus and Castanea were identified from the location of orthologous markers displaying multiple and parallel linkages.

\section{Diversity analysis}

Two experiments were carried out to provide insight into the genetic diversity of EST-SSRs. The first focused on a large number of loci in a small number of individuals of the two sympatric species $Q$. robur and Q. petraea (Additional file 2). We assessed the polymorphism of the same set of 243 oak EST-SSRs for 12 individuals from each species. DNA was extracted from leaves with the DNeasy plant mini kit (Qiagen). An M13 tail (TGT AAA ACG ACG GCC AGT) was added to the 5'-end of each forward primer, as described by Schuelke [45]. Each 
PCR was performed in a total volume of $11 \mu \mathrm{L}$ containing $1 \mathrm{x}$ PCR buffer, $200 \mu \mathrm{M}$ of each dNTP, $0.5 \mathrm{U}$ Taq polymerase (XtraTaq, Genespin, Milan, Italy), $1.5 \mathrm{mM}$ $\mathrm{MgCl}_{2}, 0.2 \mu \mathrm{M}$ of each primer, and $10 \mathrm{ng}$ of template DNA. All EST-SSR markers were amplified with an Eppendorf thermal cycler (Mastercycler, Hamburg, Germany), by a touchdown procedure: $3 \mathrm{~min}$ at $94^{\circ} \mathrm{C}, 10$ touchdown cycles of $94^{\circ} \mathrm{C}$ for $30 \mathrm{~s}, 60^{\circ} \mathrm{C}$ for $30 \mathrm{~s}\left(-1^{\circ} \mathrm{C} /\right.$ cycle), $72^{\circ} \mathrm{C}$ for $30 \mathrm{~s} ; 27$ cycles of $94^{\circ} \mathrm{C}$ for $30 \mathrm{~s}, 50^{\circ} \mathrm{C}$ for $30 \mathrm{~s}, 72^{\circ} \mathrm{C}$ for $30 \mathrm{~s}$ and a final extension at $72^{\circ} \mathrm{C}$ for $10 \mathrm{~min}$. The fluorescently labeled PCR products were separated by capillary electrophoresis, with a 400 bp size standard, in a Megabace TM 100096 capillary electrophoresis system. Alleles were sized with Fragment profiler version 1.2.

Genetic diversity parameters $\left(\mathrm{AR}, \mathrm{H}_{\mathrm{o}}, \mathrm{H}_{\mathrm{e}}\right)$ of Q. robur and $Q$. petraea were calculated using the FSTAT software package version 2.9.3 [50], which is implemented for the sample-size independent rarefaction analysis of allelic richness.

The second experiment was conceived as a proof of concept for the use of the EST-SSRs in the genetic analysis of the largely unknown semi-decidious oak species distributed around the Mediterranean basin. We genotyped 96 individuals from the two submediterranean oak species Quercus faginea and Quercus pyrenaica with 64 EST-SSRs evenly distributed among the 12 linkage groups (25 in common with the previous experiment). Additional file 3 shows the locations of the 8 populations per species that were selected to represent most of the geographic and ecological variation in the two species. DNA was extracted from leaf samples using a modified CTAB method because many of the $Q$. pyrenaica samples clogged the columns of commercial DNA extraction kits. The main modification to the standard DNA extraction procedure was the thorough chloroform extraction (3-4 times with a 1:1 volume) following cell lysis in the CTAB buffer. PCRs were performed in a total volume of $10 \mu \mathrm{L}$ containing $1 \times$ PCR buffer, $100 \mu \mathrm{M}$ of each dNTP, $0.25 \mathrm{U}$ Taq polymerase (KAPA Taq, KapaBiosystems, Boston, USA), $2 \mathrm{mM}$ $\mathrm{MgCl}_{2}, 0.045 \mu \mathrm{M}$ forward primers, $0.165 \mu \mathrm{M}$ reverse primer, $0.165 \mu \mathrm{M}$ M13-fluorescent primer and $10 \mathrm{ng}$ of template DNA. Cycling conditions consisted of an initial denaturation step $\left(94^{\circ} \mathrm{C} 5\right.$ minutes) followed by 7 touch-down cycles (from 63.7 to $59.5^{\circ} \mathrm{C}$ ), 20 cycles at $59.5^{\circ} \mathrm{C}$ annealing temperature, 12 cycles at $57.5^{\circ} \mathrm{C}$ annealing temperature and a final extension step $\left(10\right.$ minutes at $\left.72^{\circ} \mathrm{C}\right)$. The fluorescently labelled PCR products were electrophoretically separated in an ABI3130 sequencer (Applied Biosystems) using the GS500LIZ size standard. Peak sizes were scored with GeneMapper v.4.0 and allele binning was performed with MsatAllele $\mathrm{R}$ package [51]. Genetic diversity parameters $\left(\mathrm{AR}, \mathrm{H}_{\mathrm{o}}, \mathrm{H}_{\mathrm{e}}\right)$ were estimated with Fstat v.2.9.3 [50].

\section{Oak genome evolution}

Gene choice and genotyping of SNP-based markers We constructed an integrated map for Quercus based on the EST-SSRs and an additional set of SNP-based markers, for analysis of the synteny between the oak linkage map and those of other previously sequenced eudicots.

We identified 105 candidate genes (set 1) for involvement in bud burst on the basis of the following criteria: i) differential expression between the periods before and after bud flush [52], ii) colocalization with bud burst QTLs [22], and iii) a known functional role in model plants. Two types of polymorphisms were identified: in vitro SNPs/Indels from resequenced gene fragments from a panel of nine oak populations [22] and unpublished data and in-silico SNPs/Indels retrieved from expressed sequence tags [33] as described by Lepoittevin et al. [53]. Finally, 78 in vitro and 306 in silico SNPs/ Indels were included in a 384-SNP assay, including 26 insertions-deletions (indels) of between 1 and to $3 \mathrm{bp}$ in size. Full description of the SNP array is provided by Alberto et al. [54].

Genotyping was carried out on three mapping populations comprising 177, 80 and 90 F1 plants from the P1, P2 and P3 pedigrees, respectively. DNA was extracted with the Invisorb DNA plants 96 kit from Invitek (GmbH, Berlin, Germany), according to the manufacturer's instructions. Multiplex reactions were prepared with $250 \mathrm{ng}$ of template DNA per sample. Genotyping was carried out with the Illumina GoldenGate SNP genotyping platform (Illumina, San Diego, CA, USA) at the Genome-Transcriptome Facility in Bordeaux, France (http://www4.bordeaux-aquitaine.inra.fr/pgtb). The intensity of the fluorescent signals was measured with the BeadXpress Reader (Illumina Inc, San Diego, USA) and analyzed with GenomeStudio v 3.1.14 (Illumina Inc). Quality scores were generated for each genotype, using a GenCall50 (GC50) score cutoff of 0.25 and a CallRate (CR) threshold of 0.85 . These scores reflect the quality of genotype clusters (GC50) and the proportion of samples with a genotype defined for a particular SNP (CR) [55]. Genotype clusters were adjusted manually if necessary.

In addition to this first set of markers, seven candidate genes (set 2) for drought and hypoxia tolerance (from 25 genes initially screened) were found to be informative in one to three pedigrees. Two methods were used for genotyping: i) SSCP (single-strand conformation polymorphism [56], which was used for the first time on a Licor sequencer (see Additional file 4), and ii) primer 
extension with the detection of fluorescence polarization [57] with the Acycloprime-FP SNP detection kit (Perkin Elmer Life Sciences, Boston, MA, USA). Genotyping was carried out in accordance with the kit manufacturer's instructions and fluorescence was measured with a fluorescence polarization reader (Victor-Wallace from Perkin Elmer Life Sciences, Boston, MA, USA) at 20, 25 and 35 cycles.

\section{Consensus map construction}

The consensus map was constructed by joining the 10 independent parental maps based on the mapping populations in which EST-SSRs (P1 to P5) and SNP-based markers (P1 to P3) were mapped. JoinMap was first used to calculate individual maps from raw segregation data, with the Kosambi mapping function. A minimum LOD score threshold of 3.0 was used for the grouping of all markers. An integrated map was then constructed for each linkage group, by integrating the "bridge markers" common to two or more individual maps. For construction of the consensus map, we assumed that the rates of recombination between the two species and between male and female maps were uniform (but see [58]).

Using the regression algorithm of JoinMap, we obtained three maps with different levels of statistical support for ordering (denoted map1-map2-map3 in descending order of statistical support) for each linkage group. For macrosynteny analysis, we decided to retain the most reliable map (map1), adding markers with lower LOD scores as accessory markers. The position of each accessory marker relative to its most probable framework marker was then determined from the twopoint LOD scores and recombination fractions provided by the "maximum linkage" table of JoinMap. Finally, markers were assigned to $10 \mathrm{cM}$ bins within each of the 12 linkage groups of the consensus map, for the identification of regions orthologous to sequences in Arabidopsis, grape, poplar, Medicago and soybean.

\section{Evolutionary analysis}

Genome sequences The Arabidopsis (5 chromosomes 33198 genes - $119 \mathrm{Mb}$ - ftp://ftp.arabidopsis.org/home/ tair/Genes/TAIR9_genome_release/TAIR9_sequences/), grape (19 chromosomes - 21189 genes - $302 \mathrm{Mb}$ http://www.genoscope.cns.fr/externe/Download/Projets/ Projet_ML/data/), poplar (19 chromosomes - 30260 genes - $307 \mathrm{Mb}$ - ftp://ftp.jgi-psf.org/pub/JGI_data/Poplar/), Medicago (8 chromosomes - 38834 genes - $261 \mathrm{Mb}$ - ftp://ftpmips.helmholtz-muenchen.de/plants/medicago/) and soybean (20 chromosomes - 46194 genes - $949 \mathrm{Mb}$ ftp://ftp.jgi-psf.org/pub/JGI_data/phytozome/v5.0/Gmax/) genome sequences were downloaded. CDS annotations (identity, sequence, position) were considered for the synteny and duplication analyses described below. We mined the Arabidopsis, grape, poplar, Medicago and soybean sequence databases to identify genes paralogous and orthologous to the 31,798 Sanger-based oak unigenes described by Ueno et al. [33].

\section{Synteny and duplication analysis}

We used BLAST to align genomes (i.e. CDS for sequenced genomes and ESTs for oak). We used two parameters for these analyses, to take into account not only similarity but also the relative lengths of the aligned sequences: CIP (cumulative identity percentage) and CALP (cumulative alignment length percentage). CIP = $\sum[\mathrm{ID} \times(\mathrm{HSP} / \mathrm{AL}) \mathrm{x}$ 100] corresponds to the cumulative percentage sequence identity observed for all the highscoring sequence pairs (HSPs) divided by the cumulative aligned length (AL), which corresponds to the sum of all HSP lengths. CALP [AL/Query length], is the cumulative AL for all HSPs divided by the length of the query sequence. The use of these parameters for BLAST analysis resulted in the highest cumulative percentage identity over the longest cumulative length, thus maximizing stringency in the definition of conservation between the two genomes compared.

\section{Distribution of paralogous and orthologous gene pairs}

We estimated sequence divergence and dated speciation events, based on the rates of non-synonymous $(\mathrm{Ka})$ and synonymous $(K s)$ substitutions calculated with MEGA-3 [59]. The mean substitution rate $(r)$ for grasses $6.5 \times 10^{-9}$ substitutions per synonymous site per year was used to determine the ages of the genes considered $[60,61]$. The time $(T)$ since gene insertion was then estimated with the formula $T=K s / \mathrm{r}$.

\section{Results}

Functional annotation of EST-SSRS

We identified more than 52,834 EST-SSRs among the Quercus ESTs [33]. As a first step towards functional characterization of the EST-containing SSRs, we used the Slim GO classification and compared the annotations for four sets of sequences containing SSRs: coding regions (CRs), non-coding regions (NCRs), 5'UTRs and 3'UTRs. We identified 35, 7 and 19 gene categories, at "level 3", within the biological process (BP), cell compound (CC) and molecular function (MF) classes, respectively (Additional file 4). About half the SSRs in the BP class belong to four main categories: "primary metabolic processes" (11\%-13.6\%), "cellular metabolic processes" (11.7\%-14.8\%), "macromolecule metabolic processes" (8.1\%-10.6\%) and "biosynthetic processes" (7.7\%-9.9\%). For the CC class, $80 \%$ of the SSRs were assigned to the "cell part" (42.5\%$44.8 \%$ ) and "membrane-bound organelle" (30.8\%-32.3\%) categories. For the MF class, six categories of similar size 
accounted for most of the SSRs: namely "nucleic acid binding" (10.7-14.4), "protein binding" (12.5-13.5\%), "nucleotide binding" (10.5\%-11.1\%), “ion binding" (10.1\%$10.6 \%)$, "transferase activity" (9.8\%-11.3\%) and "hydrolase activity" (9.7\%-10.1\%). The distribution of these categories was similar between the four datasets (Additional file 5), indicating a lack of ability of gene ontology to discriminate between the different transcribed regions in terms of the presence of SSRs. However, slight differences between transcribed regions were nevertheless observed when all categories were considered together in a hierarchical clustering analysis (Additional file 6), but the distribution between the $\mathrm{BP}, \mathrm{CC}$ and MF classes of the four datasets remained inconsistent.

\section{SSR-based map construction in $Q$. robur and $Q$. petraea and synteny analysis Identification of polymorphic markers}

In total, we identified 573 primer pairs, which were tested for polymorphism in at least one pedigree (Table 2). Overall, 378 EST-SSRs were informative. We tested 93 of the gSSRs already available for the Fagaceae; $68(73 \%)$ were found to be polymorphic in at least one pedigree. Thus, in total, 446 polymorphic loci (68 gSSRs and 378 EST-SSRs) were available for further mapping.

\section{Construction of individual linkage maps}

Genotypic data were available for 446 loci in one to five mapping populations among them 397 were mapped. We found that $50 \%$ to $85 \%$ of the loci tested were polymorphic, depending on the pedigree. The interspecific pedigree (P2) was found to be less polymorphic than the intraspecific pedigrees (Table 2). Differences in levels of polymorphism between intra vs. interspecific pedigrees are likely be due to sampling effects, as the two species exhibit similar levels of genetic diversity and very low interspecific differentiation. The number of tested loci found to be polymorphic varied considerably between the parents, from 100 loci for P5-female (Q. robur) to 205 loci for P1-female (Q. robur). Distorted loci were more frequent for P2-female ( $Q$. robur) from the interspecific pedigree $(6.8 \%)$ than for the other pedigrees (Table 2). Unlinked loci were rare (except for both of the parental maps for P5, in which $45 \%$ of the loci were ungrouped). In the following analyses, we focused on the four pedigrees (P1 to P4) because of the smaller set of data for P5.

Linkage group (LG) statistics We constructed 12 LGs for each parental map, except for the interspecific P2male parent, for which LG11 was missing due to the fact that all markers were distorted and therefore excluded a priori from linkage map construction. Interestingly, LG11 for the P2-female parent also included four distorted loci suggesting the presence of loci involved in species incompatibility. The development and mapping of a large amount of SNP markers will certainly provide new insights into the identification and mapping of loci involved in reproductive barriers between these two hybridizing oak species.

The mean number of markers per LG was between 7.6 for LG4 and 26.9 for LG2 over the 8 maps, ("groups" with only 2 markers were not considered) (Additional file 7). The mean map length of the various LGs was between $42.2 \mathrm{cM}$ for LG4 and $85.3 \mathrm{cM}$ for LG2, with an overall mean of $58.4 \mathrm{cM}$ over the 8 maps (Additional file 8).

Table 2 Summary of polymorphism statistics for the five pedigrees (P1 to P5), Na not available

\begin{tabular}{|c|c|c|c|c|c|c|c|c|c|c|}
\hline & \multicolumn{2}{|c|}{ P1 } & \multicolumn{2}{|c|}{ P2 } & \multicolumn{2}{|c|}{ P3 } & \multicolumn{2}{|c|}{ P4 } & \multicolumn{2}{|c|}{ P5 } \\
\hline tested loci & \multicolumn{2}{|c|}{321} & \multicolumn{2}{|c|}{434} & \multicolumn{2}{|c|}{406} & \multicolumn{2}{|c|}{$\mathrm{Na}$} & \multicolumn{2}{|c|}{$\mathrm{Na}$} \\
\hline polymorphic loci & \multicolumn{2}{|c|}{$274(85 \%)$} & \multicolumn{2}{|c|}{$211(49 \%)$} & \multicolumn{2}{|c|}{$243(60 \%)$} & \multicolumn{2}{|c|}{$145(\% \mathrm{Na})$} & \multicolumn{2}{|c|}{$143(\% \mathrm{Na})$} \\
\hline marker type 1:1:1:1 & \multicolumn{2}{|c|}{133} & \multicolumn{2}{|c|}{110} & \multicolumn{2}{|c|}{130} & \multicolumn{2}{|c|}{$\mathrm{Na}$} & \multicolumn{2}{|l|}{70} \\
\hline $1: 1$ & \multicolumn{2}{|c|}{134} & \multicolumn{2}{|c|}{96} & \multicolumn{2}{|c|}{100} & \multicolumn{2}{|c|}{$\mathrm{Na}$} & \multicolumn{2}{|l|}{63} \\
\hline 1:2:1 & \multicolumn{2}{|c|}{7} & \multicolumn{2}{|c|}{5} & \multicolumn{2}{|c|}{13} & \multicolumn{2}{|c|}{$\mathrm{Na}$} & \multicolumn{2}{|l|}{10} \\
\hline EST-SSR & \multicolumn{2}{|c|}{229} & \multicolumn{2}{|c|}{167} & \multicolumn{2}{|c|}{217} & \multicolumn{2}{|c|}{122} & \multicolumn{2}{|l|}{125} \\
\hline \multirow[t]{2}{*}{$g-S S R$} & 4 & & 4 & & 2 & & & & 18 & \\
\hline & female & male & female & male & female & male & female & male & female & male \\
\hline genotyped offspring & 46 & & 84 & & 78 & & 96 & & 101 & \\
\hline discarded offspring & 0 & 0 & 6 & 4 & 0 & 1 & 3 & 4 & 10 & 11 \\
\hline polymorphic loci & 205 & 195 & 169 & 144 & 190 & 171 & 110 & 114 & 100 & 103 \\
\hline discarded loci & $0.5 \%(1)$ & $0 \%(0)$ & $0.6 \%(1)$ & $0.7 \%(1)$ & $0 \%(0)$ & $0 \%(0)$ & $2 \%(2)$ & $0 \%(0)$ & $20 \%(20)$ & $15 \%(16)$ \\
\hline distorded & $2.4 \%(5)$ & $1.5 \%(3)$ & $1.8 \%(3)$ & $6.9 \%(10)$ & $2.1 \%(4)$ & $1.8 \%(3)$ & $2.7 \%(3)$ & $0.9 \%(1)$ & $2 \%(2)$ & $3.9 \%(4)$ \\
\hline unlinked loci & $4.3 \%(9)$ & $6 \%(12)$ & $4 \%(7)$ & $7.6 \%(11)$ & $0.5 \%(1)$ & $0.6 \%(1)$ & $0 \%(0)$ & $0.9 \%(1)$ & $23 \%(23)$ & $25 \%(26)$ \\
\hline mapped loci & $93 \%$ (190) & $93 \%(180)$ & $933 \%(158)$ & $85 \%(122)$ & $975 \%(185)$ & $98 \%(167)$ & $95 \%(105)$ & $98 \%(112)$ & $55 \%(55)$ & $55 \%(57)$ \\
\hline
\end{tabular}


Estimation of total genome length The total observed map length was $572.9 \mathrm{cM}$ to $846.6 \mathrm{cM}$ (Additional file 8). Based on these partial linkage data, estimated genome sizes were obtained for various LOD score values (3, 4 and 5). They ranged from 945 to 1,611 cM (Additional file 9).

Number of alleles of mapped SSRs The number of alleles observed in the 10 parents depended on the type of motif considered: the number of loci with three or four alleles was systematically higher for loci with dinucleotide repeats than for those with trinucleotide or hexanucleotide repeats (Table 3). This trend was conserved even if we excluded gSSRs from the analysis.

Mapping with several pedigrees The genotyping of several pedigrees significantly increased the number of loci identified as polymorphic (Figure 2). P1 was the most informative pedigree in terms of mapped markers (274 polymorphic loci). However, adding P3 to the analysis increased the number of markers identified as polymorphic by $24 \%$ ( 88 new markers). Successive additional inclusions of P2, P4 and P5 increased the number of polymorphic markers identified by 35, 11 and 16 SSRs, respectively. For the 12 linkage groups obtained for each parental map, the number of markers common to at least two maps varied between 15 (LG4) and 54 (LG2) (Figure 3). The information provided by each marker for the 10 genotyped parents varied from $18.5 \%$ polymorphic loci for one parent, to $21.4 \%$ for two, $15.4 \%$ for $3,14.4 \%$ for $4,9.1 \%$ for $5,11 \%$ for 6 and less than $5 \%$ for 7 or more (Figure 4). The number of shared loci per linkage map decreased with the number of maps considered. In total, 89 mapped SSRs were common to two parental maps, whereas only two were common to nine parental maps.

\section{Consensus maps for Q. robur and Q. petraea and comparative mapping}

A consensus map for Q. robur was constructed from the seven Q. robur parental maps. This map includes 398 markers (including 179 accessory markers) and spans 933 cM (Table 4). Similarly, a consensus map for Q. petraea was established from the three parental maps available for this species. It includes 275 markers (90 accessory markers) and spans $767 \mathrm{cM}$ (Table 4, Figure 5). LG sizes varied from $61.3 \mathrm{cM}$ (LG11) to $116 \mathrm{cM}$ (LG2)

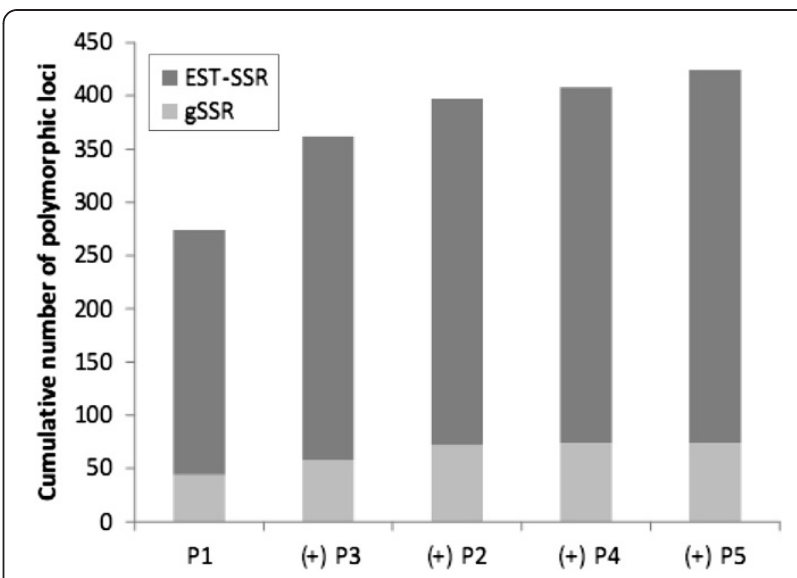

Figure 2 Information gained by genotyping several pedigrees (P1 to P5).

for Q robur and from 31.4 cM (LG11) to $120 \mathrm{cM}$ (LG9) for Q. petraea. Mean LG length was $78 \mathrm{cM}$ for Q. robur and $64 \mathrm{cM}$ for $Q$. petraea. The mean spacing between markers was $4.25 \mathrm{cM}$, with values ranging from $2.8 \mathrm{cM}$ to $6.42 \mathrm{cM}$ (Table 5).

The consensus species maps were compared for the analysis of genomic organization and structural rearrangements. A high degree of macrocollinearity was observed between the two maps, based on 100 common markers evenly distributed over the 12 LGs (Figure 5). Some order discrepancies occurred in small sections of LGs, as in LG2 and LG3, for example. Furthermore, the positions of a few markers were inconsistent over larger distances. For example, GOT009 was localized to the top of LG1 for Q. petraea but was found in the center of this LG in Q. robur. It should also be noted that LG11 was split into two parts in Q. petraea.

Transferability of EST-SSRs to other members of the Fagaceae and Nothofagaceae and comparative mapping of Quercus and Castanea

\section{Transferability of EST-SSRs}

We assessed the transferability of 198 EST-SSR markers to Q. ilex and Q. suber, of 194 markers to C. sativa and F. sylvatica, and 126 markers to $N$. pumilio and N. antarctica (Additional file 10). A PCR product of the expected size was amplified in at least one of the Fagaceae or Nothofagaceae species for $91.8 \%(223 / 243)$ of the EST-SSRs tested. Within the Fagaceae family, transferability was greatest for

Table 3 Type of SSR motifs for the five pedigrees

\begin{tabular}{lllll}
\hline Motif type & Number of loci/motif type & \multicolumn{3}{l}{ Number of alleles } \\
\cline { 3 - 5 } & & $\mathbf{2}$ & $\mathbf{3}$ & $132(0.26 \%)$ \\
$\mathrm{di}$ & 503 & $200(0.4 \%)$ & $58(0.22 \%)$ & $\mathbf{4}$ \\
tri & 259 & $163(0.63 \%)$ & $4(0.34 \%)$ & $38(0.15 \%)$ \\
hexa & 59 & $16(0.27 \%)$ & $4(0.07 \%)$ & $1(0.02 \%)$ \\
\hline
\end{tabular}




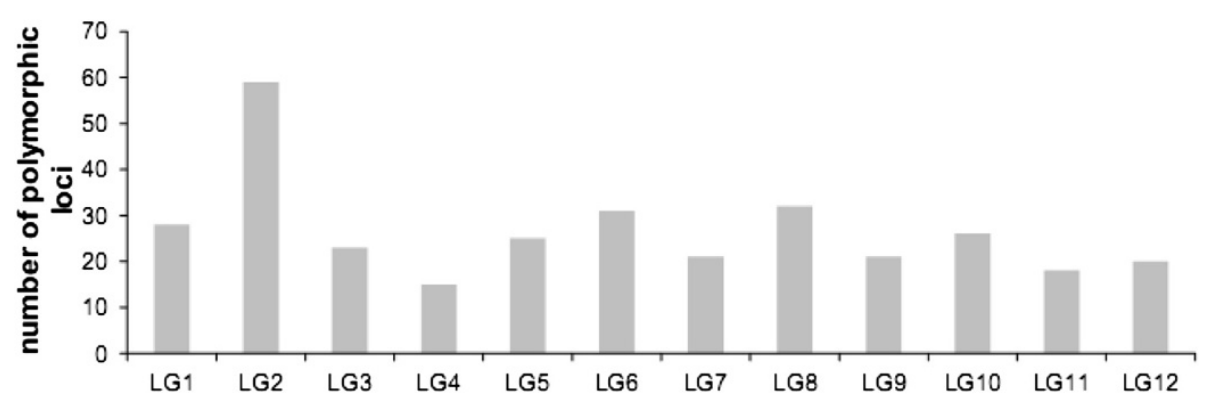

Figure 3 Distribution of common loci per LG for at least two maps.

the two white oaks (Q. faginea and Q. pyrenaica), with transferability rates close to $100 \%$ (a few EST-SSRs amplified products that could not be analyzed due to extra bands and/or duplicated genes). Transferability was intermediate for Q. suber, Q. ilex and C. sativa, with rates of $70.7 \%, 69.7 \%$ and $68 \%$ respectively. The lowest transferability within the Fagaceae family was observed in Fagus sylvatica, with only $14.4 \%$ of transferable markers. Levels of transferability to Nothofagaceae species were very low. Only 12 and 15 markers were successfully transferred to $N$. pumilio and $N$. antarctica, respectively.

\section{Comparative mapping}

We mapped 555 polymorphic markers in Castanea (Table 6), 91 of which were common (63 EST-SSRs, 16 gSSRs, 12 EST-P) to the consensus Quercus map. For all 12 Castanea LGs (LG-C), homologous linkage groups were identified in Quercus (LG-Q), with four to 17 markers shared for LG4-C (= LG5-Q) and LG1-C (= LG2-Q), respectively (Table 7). A set of 16 markers was located on linkage groups that were not homologous between Castanea and Quercus. Overall, macrosynteny was well conserved between the two genera, despite the inversion of a few markers (illustrated for one LG in Figure 6 and supported for all LGs in Additional file 11).

\section{Diversity analysis}

A high-quality amplification product was obtained for $83.8 \%$ (166) of the 198 markers studied in the first experiment and $94.6 \%$ (157) were found to be polymorphic in at least one natural population of $Q$. robur and Q. petraea. In the two populations considered, expected heterozygosity $\left(H_{e}\right)$ ranged from low $(0.100$ and 0.091 , for $Q$. robur and $Q$. petraea, respectively) to high (0.939 and 0.964 , respectively) values. Diversity levels (allelic richness and $H_{e}$ ) were similar in the two species.

Diversity levels were rather similar in the two submediterranean Quercus species (Additional file 12). All diversity estimates were largest for EST-SSRs with dinucleotide repeat motifs. However, differences were small between tri and hexanucleotide EST-SSRs in these two oaks. The same trend was observed for Q. robur and Q. petraea.

\section{Oak genome evolution}

Construction of a gene-based consensus linkage map Individual maps were constructed from EST-SSRs (see above) and SNPs. For SNP-based markers, 105 (set 1) and 7 (set 2) candidate genes were genotyped in three mapping populations: 56 (set 1 ) and 4 (set 2) were localized on at least one of the six parental maps (Additional file 1 and

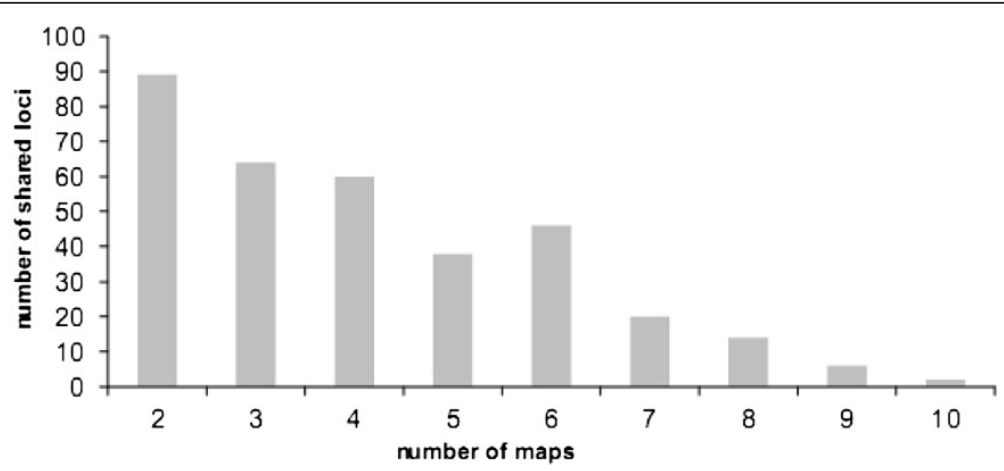

Figure 4 Number of shared loci between two to ten parental maps. 
Table 4 LG size (in CM) for both species, Q. robur and Q. petraea

\begin{tabular}{|c|c|c|c|c|c|c|c|c|c|c|c|c|c|c|}
\hline$n^{\circ}$ LG & LG1 & LG2 & LG3 & LG4 & LG5 & LG6 & LG7 & LG8 & LG9 & LG10 & LG11 & LG12 & tot & mean \\
\hline Q. robur & 84.4 & 116 & 81.5 & 62.3 & 76.8 & 74 & 63.6 & 101 & 71.1 & 76.6 & 61.3 & 64.2 & 933 & 77.8 \\
\hline Q. petraea & 81.4 & 84.8 & 64.8 & 47.5 & 64.2 & 62.8 & 47 & 66.5 & 120 & 48 & 31.4 & 48.3 & 767 & 63.9 \\
\hline
\end{tabular}

Additional file 13). The consensus map included 381 loci (321 EST-SSRs and 60 SNP-based markers), 19 of which (18 EST-SSRs and 1 SNP) were considered to be paralogous and were assigned to different bins (on different LGs) on different individual maps. The mean number of markers mapped per LG was 32, with a maximum of 72 markers mapped for LG2 and a minimum of 22 for LG7, LG10 and LG11. Markers were assigned to 86-10 cM bins within each of the 12 linkage groups of the consensus map, for the identification of regions orthologous to regions from Arabidopsis, grape, poplar, Medicago, and soybean.

\section{Synteny and duplication analysis}

Independent intraspecific (i.e. paralogs) and interspecific (i.e. orthologs) comparisons are required for the precise inference of paralogous or orthologous gene relationships between oak and other eudicots and to determine the precise history of oak evolution from the known ancestor of eudicot genomes.

Using the alignment parameters and statistical tests described in the methods section, we analyzed the syntenic relationships between oak, Arabidopsis, poplar,
Medicago, grape and soybean [62]. Using grape as the reference genome - this species being the closest relative of the eudicot ancestor, with a genome structured into seven protochromosomes (color code used for chromosome painting) -124 orthologous relationships were identified (Figure 7) covering $50 \%$ of the oak genome [3]. The following chromosome-to-chromosome relationships were then established (o for oak and $\mathbf{g}$ for grape): o1/g17, o2/g4-g11-g14, o3/g14, o5/g12-g19, o6/ g4-g5, o7/g8, o8/g6-g10-g12-g19, o10/g17, o11/g3, o12/ g2-g15.

Five major duplications were also identified, covering $28 \%$ of the genome and involving the following chromosome-to-chromosome relationships: o1-o2-o10 (yellow), o6-o11 (green), o3-o6 (purple), o7-o8 (brown), o5-o8 (red) (Figure 8).

The integration of independent analyses of duplications within and synteny between the five major eudicot genomes led to the precise characterization in oak of five of the seven paleoduplications recently identified as the basis of the definition of seven ancestral chromosomal groups in eudicots [63]. These ancestral shared duplications were found on the following chromosome-pair combinations in
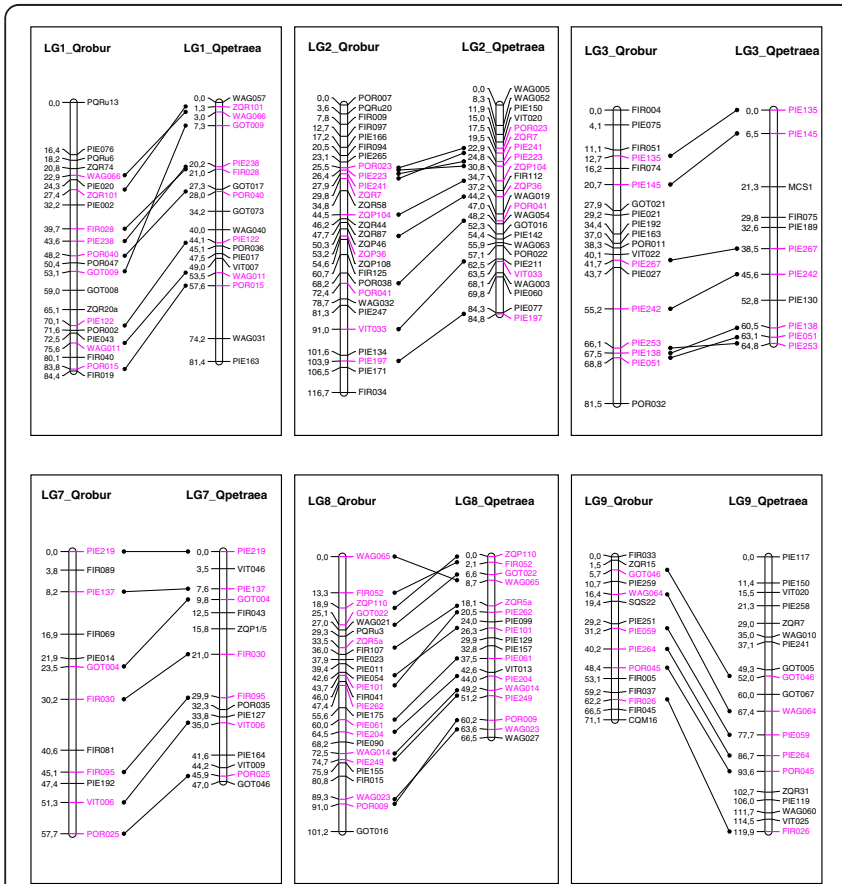
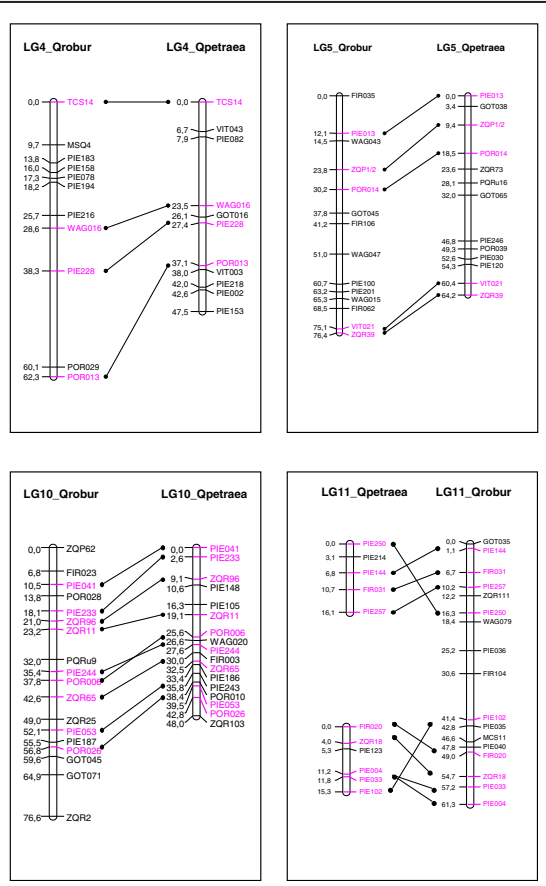
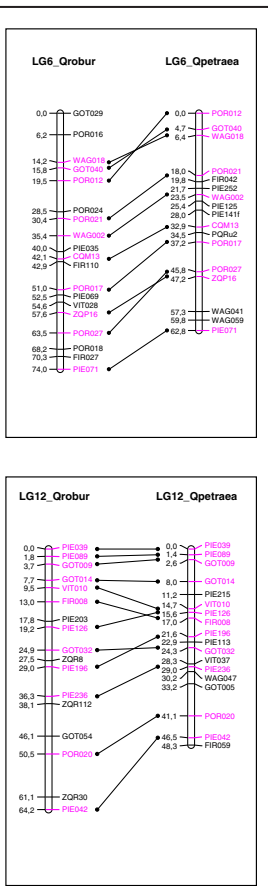

Figure 5 LG consensus species maps of Q. robur and Q. petraea. 
Table 5 Mean distance between two loci for each LG and both species, Q. robur and Q. petraea

\begin{tabular}{|c|c|c|c|c|c|c|c|c|c|c|c|c|c|}
\hline mean dist loci/cM & LG1 & LG2 & LG3 & LG4 & LG5 & LG6 & LG7 & LG8 & LG9 & LG10 & LG11 & LG12 & mean \\
\hline Q. robur & 2.8 & 1.2 & 2.7 & 3.3 & 2.5 & 2.1 & 2.9 & 2.8 & 2.7 & 2.7 & 2.5 & 2.9 & 2.6 \\
\hline Q. petraea & 3.4 & 2.0 & 4 & 2.4 & 2.8 & 2.2 & 3.9 & 2.1 & 4.1 & 2.4 & 2.8 & 2.7 & 2.9 \\
\hline
\end{tabular}

oak, the locations of the seven ancestral paleoduplications in grape also being indicated : g1-g14-g17/o1-o2-o10, g2g15-g12-g16/[not identified in oak], g3-g4-g7-g18/o6-o11, g4-g9-g11/[is partially fused into o2], g5-g7-g14/o3-o6, g6-g8-g13/o7-o8, g10-g12-g19/o5-o8. Thus, five of the seven previously identified ancestral shared duplications are characterized here for the first time in oak. Based on the ancestral and lineage-specific duplications already reported for eudicots, an evolutionary scenario can be developed in which the 12 oak chromosomes evolve from the seven chromosomes of the eudicot ancestor or, more precisely, from the 21 chromosomes resulting from polyploidization of the paleohexaploid intermediate (Figure 9). We suggest that at least eight major ancestral chromosome fusions (Cf) occurred to yield the current 12-chromosome structure, and that this process involved an intermediate ancestor that also had 12 chromosomes (Figure 9).

\section{Discussion}

Our results provide new biological information about certain features of oak EST-SSRs, the benefits of linkage mapping with multiple pedigrees, the macrosynteny between two interfertile oak species $(Q$. robur and $Q$. petraea) and between two closely related genera (Quercus

Table 6 Segregating and mapped markers in Castanea sativa

\begin{tabular}{lccc}
\hline & & \multicolumn{2}{c}{ Castanea } \\
\hline genotyped samples & & \multicolumn{2}{c}{50 } \\
polymorphic loci & & 502 & \\
segregation type & $1: 1$ & & 50 \\
& $1: 1: 1: 1$ & 3 & \\
& $1: 2: 1$ & female & male \\
markers type & & 183 & 149 \\
& RAPD & 31 & 14 \\
& AFLP & 32 & 25 \\
EST-P & 27 & 28 \\
distorted loci & gSSR & 60 & 55 \\
discarded loci & EST-SSR & 333 & 271 \\
unlinked loci & total & $12(3.6 \%)$ & $8(3 \%)$ \\
mapped loci & & 20 & 10 \\
\hline
\end{tabular}

and Castanea), and about the evolution of the oak genome from the ancestor of the eudicot genome.

\section{Characteristics of oak EST-SSRs}

As reported in other species [64], [9], dinucleotide-SSRs (di-SSRs) occurred preferentially within UTR regions, whereas trinucleotide-SSRs (tri-SSRs) that do not interfere with the reading frame occurred mostly in the coding regions of oak ESTs. The rate of polymorphism was also higher for di-SSR loci than for tri-SSR loci (72\% vs. $65 \%$ (Table 3)), suggesting that SSRs occurring within UTRs are more polymorphic than those in coding regions. The number of alleles was also larger for di-SSR loci than for tri-SSR loci (60\% of di-SSRs presented three or four alleles per locus, versus $37 \%$ of tri-SSRs (Table 3). A similar pattern has been reported for other species, such as castor bean [65] and cotton [66].

EST-SSRs were highly transferable between Fagaceae species, consistent with findings for other dicots, such as Prunus [13], Camellia [67], Citrus [15] and other species (reviewed in [10]), demonstrating a higher degree of transferability across taxonomic boundaries for EST-SSR markers than for genomic SSRs [68]. As expected, the transferability of Quercus EST-SSRs decreased with increasing phylogenetic distance between the species concerned. Furthermore, more than $75 \%$ of EST-SSR markers displayed high levels of genetic diversity in natural populations of Q. robur and Q. petraea. Thus, ESTSSR loci can generate sufficient polymorphism to

Table 7 Correspondence between LG in Quercus (this study) and Castanea (following the nomenclature of Casasoli et al. [27])

\begin{tabular}{ll}
\hline LG_Q & LG_C \\
\hline 1 & 6 \\
2 & 1 \\
3 & 8 \\
4 & 2 \\
5 & 4 \\
6 & 11 \\
7 & 5 \\
8 & 7 \\
9 & 9 \\
10 & 10 \\
11 & 3 \\
12 & 12 \\
\hline
\end{tabular}




\section{LG1 Castanea}

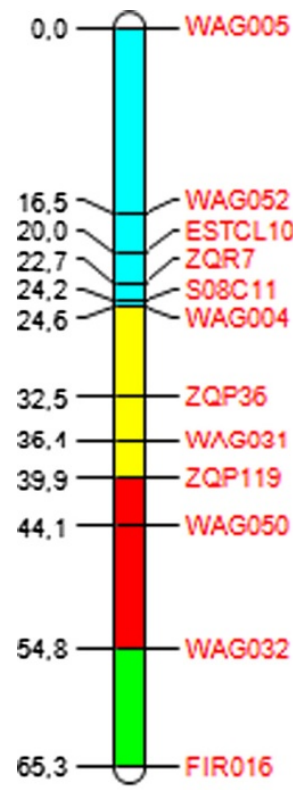

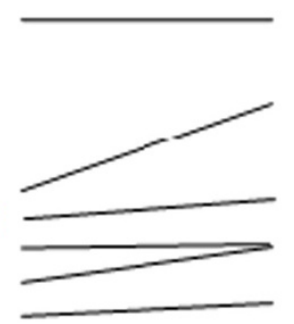

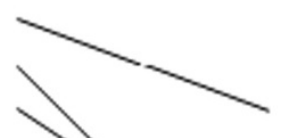

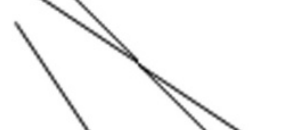

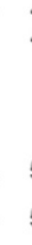

\section{LG2 Quercus}

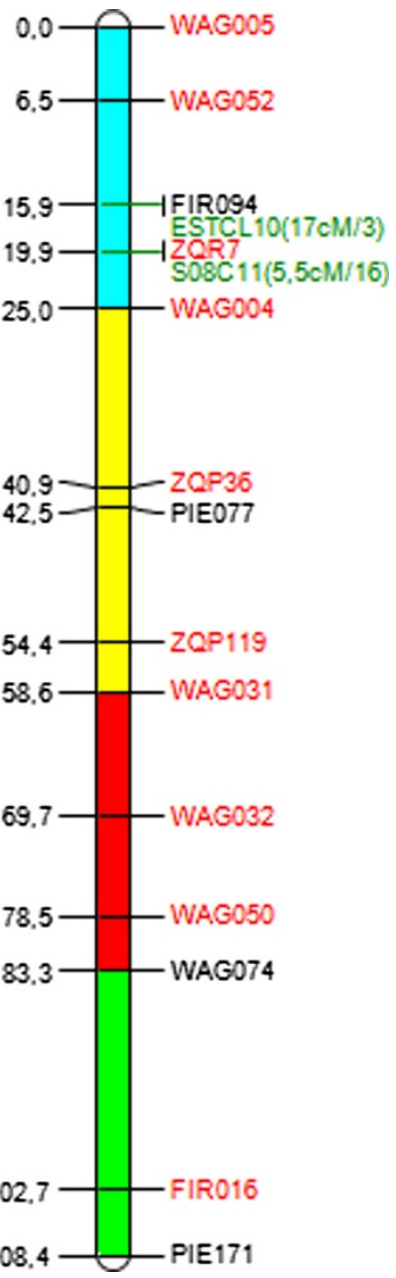

Figure 6 Synteny between Quercus and Castanea for LG1. Loci in red are common for both species, loci in green are located as accessory loci (theta/LOD), parts of linkage group which are represented by the same colour correspond to homologous segments between the two species.

constitute a valuable source of functional SSR markers for population genetic studies within the Fagaceae. As a proof of concept, we used two other Quercus species ( $Q$. faginea and $Q$. pyrenaica) to provide the foundations for the use of a set of EST-SSR markers for comparative population genetic studies of the almost 20 species of deciduous oaks in the Mediterranean region. The high transferability rates into such species and the elevated polymorphims grant the use of our set of EST-SSRs for such purposes.

\section{Linkage mapping with multiple pedigrees}

Mapping based on multiple segregating populations has several advantages over mapping based on a single pedigree. First, such strategies make it possible to map much larger numbers of markers. In this study, 274 loci were mapped in the most polymorphic mapping population
(P1), but the analysis of four more pedigrees made it possible to map another 145 loci. The L-shaped distribution of the number of markers common to the different populations (Figure 4) clearly demonstrates that the number of polymorphic markers suitable for mapping increases with the number of pedigrees considered. A consensus map for oak is currently being constructed on a much larger scale, with SNP-based markers genotyped in four oak pedigrees with a total of 1,100 offspring. The addition of several thousand gene-based markers will provide a valuable tool for the alignment of genomic scaffolds from the oak genome (which is currently being sequenced) with a linkage map, with a view to establishing pseudochromosomes.

Second, based on comparisons of the positions of the mapped markers in the various populations, we identified 26 loci $(6 \%)$ with different linkage group positions 


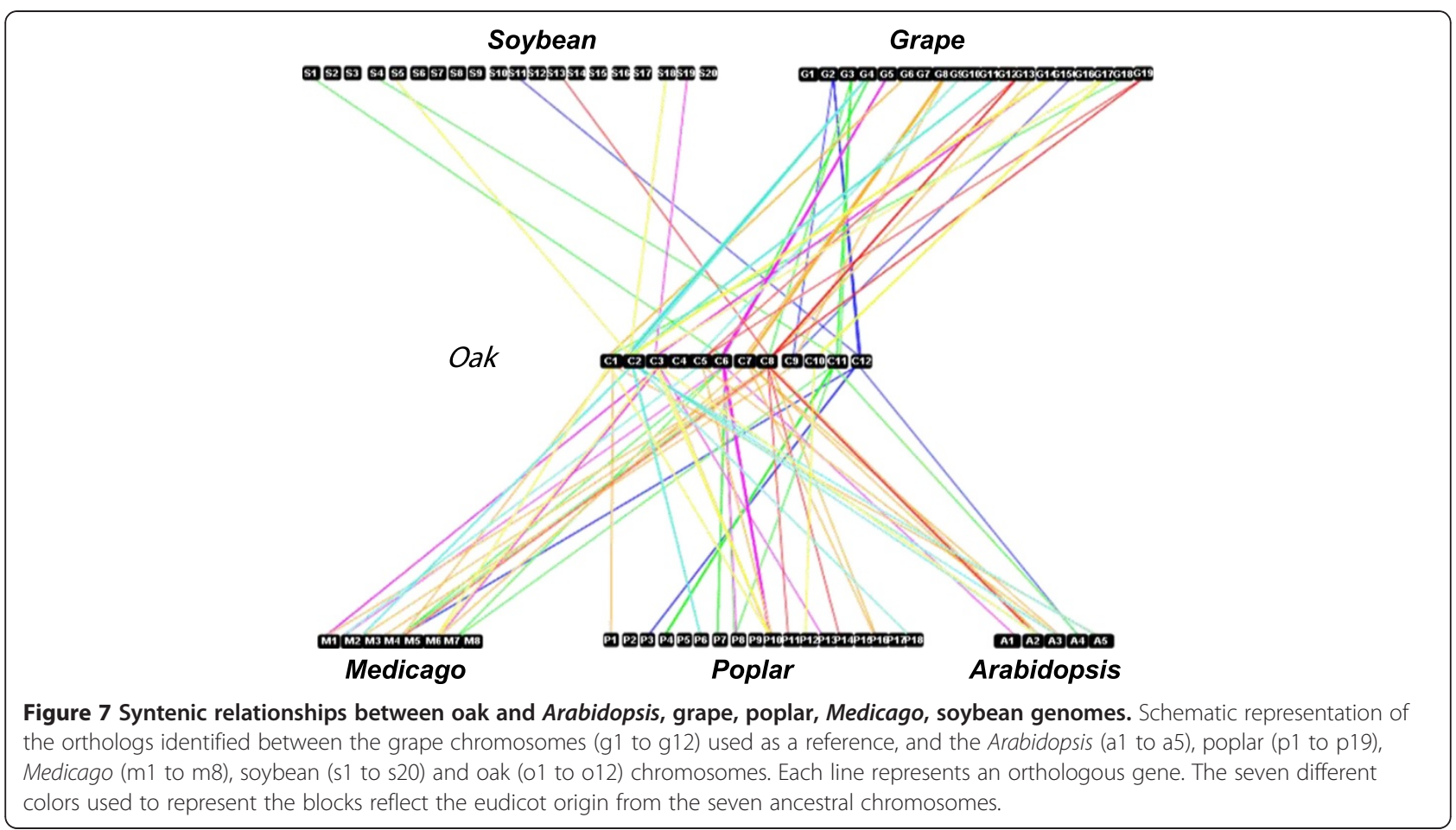

in different populations (25 assigned to two LGs and one assigned to three LGs), suggesting that different paralogs were indeed amplified in different genetic backgrounds, probably due to nucleotide variability at

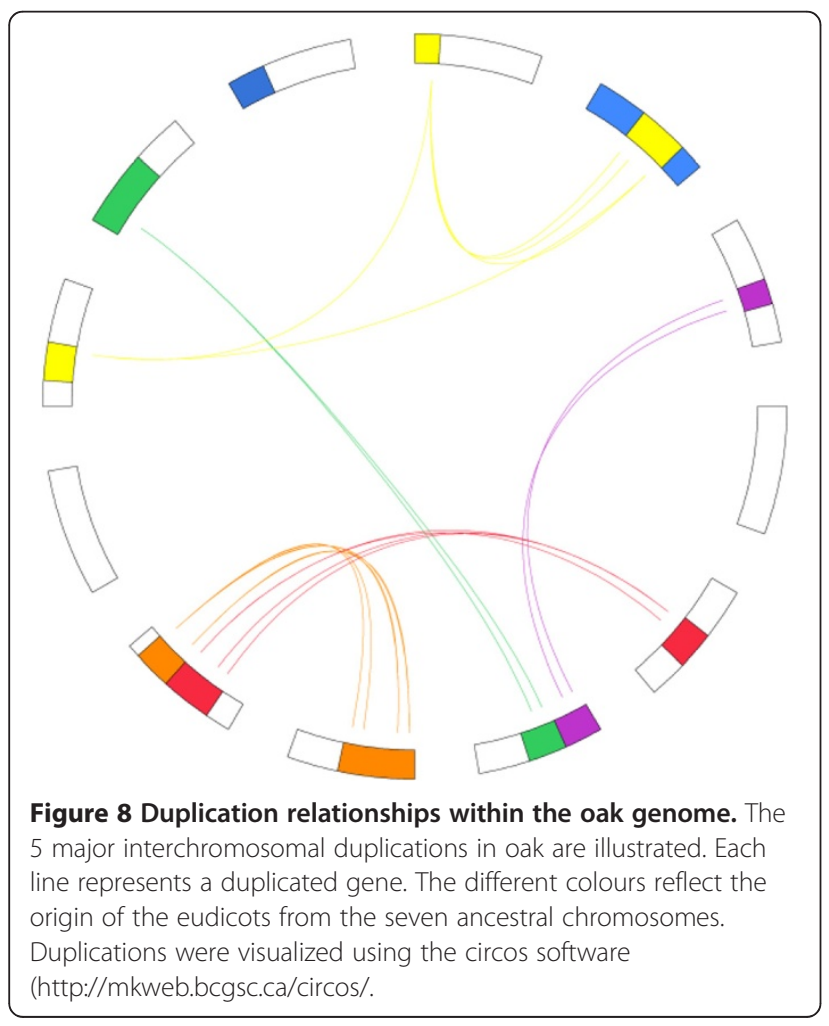

priming sites. In most cases, the discrepancies observed concerned parental maps for different pedigrees, but no such trend was identified concerning the species origin of the paralogous loci. Interestingly, eight of the 16 annotated sequences corresponding to proteins of known function belong to multiple gene families (e.g. ribosomal, RNA-binding, thioredoxin, O-methyl transferase proteins).

Finally, the establishment of linkage maps for multiple pedigrees within a species is also a prerequisite for multiple pedigree-based QTL detection strategies aiming to identify and validate QTLs in a broad genetic background [69-73]. To this end, a total of 100 EST-SSRs evenly spaced and common to the six parental maps of P1, P2 and P3 have been chosen and will be genotyped in 150 to $300 \mathrm{~F} 1 \mathrm{~s}$ for the identification of QTLs for adaptive traits (e.g. bud phenology - unpublished results).

\section{Comparative mapping of oak species that hybridize} naturally: Q. robur and Q. petraea, and beyond

We present here the first genetic maps for two interfertile white oak species, making it possible to trace chromosomal changes [74]. A relatively large proportion (323/ 397; 81\%) of the loci mapped was common to at least two parental maps. The integrated species maps of 397 loci covered all 12 LGs, with a mean distance between markers of $2.60 \mathrm{cM}$ for Q. robur and $2.91 \mathrm{cM}$ for Q. petraea. As expected, the total length of the integrated maps was greater than the length of the individual maps, as previously reported for Vitis [75], Lactuca [72] and Picea [76]. 


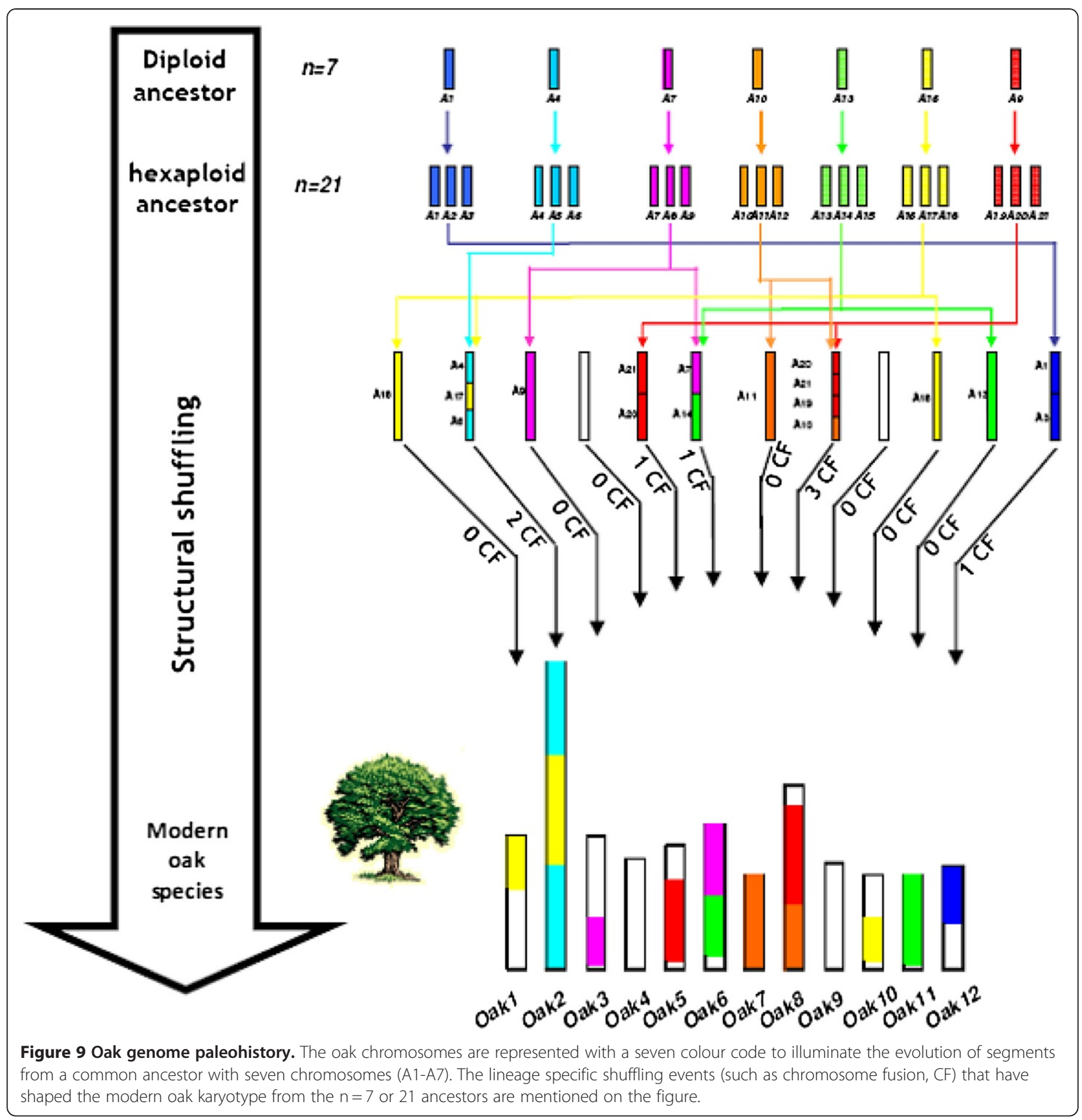

These results suggest that integrated maps probably cover regions not covered by the individual maps, in distal positions on the chromosomes. The genome lengths of the two consensus maps were very different $-933 \mathrm{cM}$ for $Q$. robur and $767 \mathrm{cM}$ for Q. petraea - despite the similar physical size of the two genomes [77]. This discrepancy may reflect differences in recombination rates between $Q$. robur and $Q$. petraea or differences in recombination rate in these particular genotypes. The overall macrocollinearity between these two species maps was high, with little shuffling of marker order between homologous LGs. Some local inconsistencies in marker order were observed, as reported for other species [72,75,78,79], but no duplication or major chromosomal rearrangement (inversion, translocation) was characterized. This high degree of collinearity should facilitate the identification of genomic islands involved in species differentiation [80,81].

A comparison of the consensus maps of Quercus and Castanea revealed a high degree of collinearity and synteny between the 12 homologous linkage groups, despite the divergence of their lineages 70 million years ago [82]. A search for genes underlying similar QTLs, based 
on comparative mapping, could be considered, making use of the sequencing data available for Castanea.

\section{Oak genome evolution}

We have identified precise chromosomal relationships within the oak genome corresponding to the ancestral hexaploidization event reported in eudicots [83]. This made it possible to propose an evolutionary scenario describing the development of the modern oak genome from the ancestral eudicot karyotype over the last 100 million years. Such information is of prime importance for gene cloning and, for example, detecting gene function by complementing Arabidopsis mutants. The ancestral hexaploidization event in eudicots generated two additional copies for any ancestral gene function considered [3]. In modern eudicot species, these three homologous copies may have or may not have retained the same function as the ancestral gene. It is thus of the utmost importance, when cloning candidate genes on the basis of synteny (i.e. translational genomics approach with the use of reference (i.e. sequenced) genomes), to investigate all the duplicated copies, which may prove to be redundant or complementary in terms of their function and the phenotype they confer [84].

\section{Conclusion}

This study provides new insights into the distribution of EST-derived SSRs between five mapping populations of two oak species and the benefits of using multiple pedigrees for the construction of consensus maps. We mapped 397 loci, $81 \%$ of which were common to at least two different mapping populations. The level of conserved macrosynteny was very high between $Q$. robur and Q. petraea, as well as between Quercus spp. and Castanea sativa, opening perspectives for QTL validation across phylogenetically related species as demonstrated by Faivre Rampant et al. [85].

Functional characterization of these EST-derived oak SSRs revealed many genes with biological, cellular and molecular functions. Their position is now being compared to that of already mapped QTLs and suggest putative positional candidate genes that are being used as anchor markers to fine map large effect QTLs (e.g. for water use efficiency and bud burst) and identify the underlying sub genomic region using the BAC libraries available for Quercus robur [85].

\section{Additional files}

Additional file 1: Description of SSR markers (locus name, forward and reverse primers, EST sequences, accessions number).

Additional file 2: Description of location of the $Q$. robur and $Q$. petraea individuals used for diversity analyses.
Additional file 3: Map of the populations location of $Q$. faginea and $Q ;$ pyrenaica used for the diversity analyses.

Additional file 4: Description of the SSCP method implemented on a Licor DNA sequencer.

Additional file 5: Comparison of Gene Ontology classification between the four sets of sequences containing EST-SSRs (CR: Coding Region, NCR: Non Coding Region, 5'UTR: 5' Un-Transcribed Region, 3'UTR: 3' Un-Transcribed Region. The relative frequencies of GO hits for oak sequences are assigned to the GO functional categories (Cellular Compounds, Molecular Function and Biological Process.

Additional file 6: Clustering of Blast2GO categories using the four sets of sequences containing EST (CR: Coding Region, NCR: Non Coding Region, 5'UTR: 5' Un-Transcribed Region, 3'UTR: 3' UnTranscribed Region).

Additional file 7: Number of loci per LG for the five pedigrees (in () data for two partial linkage group, acc: accessory markers, tot: total number of markers).

Additional file 8: Map length in $\mathrm{CM}$ of the ten parental maps (in () are written the values obtained for two partial linkage groups).

Additional file 9: Estimation of genome length in $\mathrm{CM}$ for LOD score ranging from 3 to 5 .

Additional file 10: Transferability results for EST-SSR loci tested on Castanea sativa, Fagus sylvatica, Quercus faginea, Q. pyrenaica, $Q$. ilex, Q. suber, Nothofagus pumilio and N. antartica.

Additional file 11: Linkage groups homology between Castanea and Quercus.

Additional file 12: Diversity results for Quercus robur, $Q$. petraea; $Q$. faginea and $Q$. pyrenaica (LG: Linkage group, AR: allelic richness, $\mathrm{H}_{\mathrm{o}}$ : observed heterozygosity, $\mathrm{H}_{\mathrm{e}}$ : expected heterozygosity).

Additional file 13: List of the all mapped SNPs, annotation and map location.

\section{Authors' contributions}

CB1, EC, OG, JD, HPK, PGG: developing and genotyping EST-SSRs in oak mapping populations; FB, GGV, CS, FV, CM: EST-SSR transferability in the Fagaceae and Nothofagaceae, diversity analysis in natural populations of oaks, and contribution to the genotyping of oak and chestnut pedigrees; PGG: transferability and polymorphism analysis of EST-SSRs in the submediterranean oaks; CB1, EC, CP: linkage mapping; EC, FA, CB2: SNP analysis; $F M, J S, C P$ analysis of oak genome evolution; FV, GR: plant material preparation; JPS: database entries and analysis, CB1, CP, JS, manuscript preparation, $C B 1, C P, A K$ : project design; $C P, A K$ : funding and overall supervision. All the authors have read and approved the manuscript.

\section{Acknowledgements}

The study was funded by the European Commission under the FP6 program (FP6-2004-GLOBAL-3, Network of Excellence EVOLTREE "Evolution of Trees as Drivers of Terrestrial Biodiversity", No. 016322) and FP7 program (FP7-244096, Foresttrac: Forest ecosystem genomics Research: supporTing Transatlantic Cooperation). Studies of transferability to $Q$. faginea - Q. pyrenaica were supported by grant CGL2009-07670 from the Ministry of Science and Innovation (Spain) to PGG. CS was supported by a Consejo Nacional de Investigaciones Científicas y Técnicas (CONICET, Argentina) grant. This paper is dedicated to Marie Pierre Reviron. Marie Pierre's support was immense throughout the Evoltree workplan, and the collaborative mapping activities of this project were substantially facilitated by her contribution.

\section{Author details}

'INRA, UMR1202 BIOGECO, Cestas F-33610, France. ${ }^{2}$ Université de Bordeaux, UMR1202 BIOGECO, Cestas F-33610, France. ${ }^{3}$ Forest Genetics and Forest Tree Breeding Büsgen Institute Faculty of Forest Sciences and Forest Ecology Göttingen University, Büsgenweg 2, 37077, Göttingen, Germany. ${ }^{4}$ Plant Genetics Institute, National Research Council, Via Madonna del Piano 10, Sesto Fiorentino, FI 50019, Italy. ${ }^{5}$ Plant Protection Institute, National Research Council, Via Madonna del Piano 10, Sesto Fiorentino, Fl 50019, Italy.

${ }^{6}$ NEIKER-Tecnalia, Dpto Biotecnologia, PO Box 46, Vitoria-Gasteiz 01080, Spain. 'Unidad de Genética Ecológica y Mejoramiento Forestal, INTA EEA Bariloche, 
Bariloche CC277 8400, Argentina. ${ }^{8} \mathrm{CNR}$ Istituto di Biologia Agroambientale e Forestale, Porano, TR 05010, Italy. ${ }^{9}$ ALTERRA Wageningen UR, PO Box 47Wageningen 6700 AA, The Netherlands. ${ }^{10}$ INRA, UMR1095 GDEC, Clermont-Ferrand F-63100, France. ${ }^{11}$ New address: School of Forest Resources and Environmental Science, Michigan Technological University, Houghton, MI 49931, USA.

Received: 27 March 2012 Accepted: 22 August 2012

Published: 29 August 2012

\section{References}

1. Bernardo R: Molecular markers and selection for complex traits in plants: Learning from the last 20 years. Crop Science 2008, 48(5):1649-1664.

2. Bergelson J, Roux F: Towards identifying genes underlying ecologically relevant traits in Arabidopsis thaliana. Nat Rev Genet 2010, 11:867-879.

3. Abrouk M, Murat F, Pont C, Messing J, Jackson S, Faraut T, Tannier E, Plomion C, Cooke R, Feuillet C, Salse J: Paleogenomics of plants: modern species synteny-based modelling of extinct ancestors. Trends Plant Sci 2010, 15:479-487.

4. Troggio M, Malacarne G, Coppola G, Segala C, Dustin A, Cartwright DA, Pindo M, Stefanini M, Mank R, Moroldo M, Morgante M, Grando MS, Velasco R: A Dense Single-Nucleotide Polymorphism-Based Genetic Linkage Map of Grapevine (Vitis vinifera L.) Anchoring Pinot NoirBacterial Artificial Chromosome Contigs. Genetics 2007, 176:2637-2650.

5. Tanksley SD, Martin W, Ganal MW, Martin GD: Chromosome landing: a paradigm for map-based gene cloning in plants with large genomes. Trends Genet 1995, 11:63-68.

6. Remington DL, Ungerer MC, Purugganan MD: Map-based cloning of quantitative trait loci: progress and prospects. Genet Res 2001, 78:213-218.

7. Lefebvre-Pautigny F, Wu F, Philippot M, Rigoreau M, Priyono, Zouine M, Frasse P, Bouzayen M, Broun P, Pétiard V, Tanskley SD, Crouzillat D: High resolution synteny maps allowing direct comparisons between the coffee and tomato genomes. Tree Genetics Genomes 2010, 6(4):565-577.

8. Muñoz A, Zheng C, Zhu Q, Albert VA, Rounsley S, Sankoff D: Scaffold filling, contig fusion and comparative gene order inference. BMC Bioinformatics 2010, 11:304. doi:10.1186/1471-2105-11-304.

9. Studer B, Asp T, Frei U, Hentrup S, Meally H, Guillard A, Barth S, Muylle H, Roldán-Ruiz I, Barre P, et al: Expressed sequence tag-derived microsatellite markers of perennial ryegrass (Lolium perenne L.). Mol Breeding 2008, 21:533-548.

10. Ellis JR, Burke JM: EST-SSR as a resource for population genetic analyses. Heredity 2007, 99:125-132.

11. Fouet $\mathrm{O}$, Allegre $\mathrm{M}$, Argout $\mathrm{X}$, Jeanneau M, Lemainque A, Pavek S, Boland $\mathrm{A}$, Risterucci AM, Loor G, Tahi M, Sabau X, Courtois B, Lanaud C: Structural characterization and mapping of functional EST-SSR markers in Theobroma cacao. Tree Genetics and Genomes 2011, 7:799-817.

12. Moccia M, Oger-Desfeux C, Marais G, Widmer AA: White Campion (Silene latifolia) floral expressed sequence tag (EST) library: annotation, EST-SSR characterization, transferability, and utility for comparative mapping. BMC Genomics 2009, 10:243-257.

13. Mnejja M, Garcia-Mas J, Audergon JM, Arús P: Prunus microsatellite marker transferability across rosaceous crops. Tree Genetics and Genomes 2010, 10:689-700

14. Xie WG, Zhang XQ, Cai HW, Liu W, Peng Y: Genetic diversity analysis and transferability of cereal EST-SSR markers to orchardgrass (Dactylis glomerata L.). Biochem Syst Ecol 2010, 38(4):740-749.

15. Luro F, Costantino G, Terol J, Argout $X$, Allario T, Wincker P, Talon M, Ollitrault P. Morillon R: Transferability of the EST-SSRs developed on Nules clementine (Citrus clementina Hort ex Tan) to other Citrus species and their effectiveness for genetic mapping. BMC Genomics 2008, 9:287-300.

16. Kremer A, Vinceti B, Alia R, Burczyk J, Cavers S, Degen D, Finkeldey R, Fluch S, Gömöry D, Gugerli F, Koelewijn HP, Koskela J, Lefèvre F, Morgante M, Mueller-Starck G, Plomion C, Taylor G, Turok J, Savolainen O, Ziegenhagen B: Forest Ecosystem genomics and adaptation: Evoltree Conference Report. Trees Genetics and Genomes 2011, 7:869-875.

17. Barreneche $T$, Bodénès $C$, Lexer $C$, Trontin JF, Fluch $S$, Streiff $R$, Plomion $C$, Roussel $\mathrm{G}$, Steinkellner $\mathrm{H}$, Burg $\mathrm{K}$, et al: A genetic linkage map of Quercus robur $\mathrm{L}$. (pedunculate oak) based on RAPD, SCAR, microsatellite, minisatellite, isozyme and 55 rDNA markers. Theor Appl Genet 1998, 97(7):1090-1103.
18. Casasoli M, Mattioni C, Cherubini M, Villani F: A Genetic Linkage map of European chestnut (Castanea sativa Mill). based on RAPD, ISSR and isozyme markers. Theor Appl Genet 2001, 102(8):1190-1199.

19. Kubisiak TL, Hebard FV, Nelson CD, Zhang J, Bernatzky R, Huang $H$ Anagnostakis SL, Doudrick RL: Molecular mapping of resistance to blight in an interspecific cross in the genus castanea. Phytopathology 1997, 87(7):751-759.

20. Scalfi M, Troggio M, Piovani P, Leonardi S, Magnaschi G, Vendramin GG, Menozzi P: A RAPD, AFLP and SSR linkage map, and QTL analysis in European beech (Fagus sylvatica L.). Theor Appl Genet 2004, 108(3):433-441.

21. Scotti-Saintagne C, Bodénès $C$, Barreneche T, Bertocchi E, Plomion C, Kremer A: Detection of quantitative trait loci controlling bud burst and height growth in Quercus robur L. Theor Appl Genet 2004, 109(8):1648-1659.

22. Derory J, Scotti-Saintagne C, Bertocchi E, Le Dantec L, Graignic N, Jauffres A, Casasoli M, Chancerel E, Bodénès C, Alberto F, Kremer A: Contrasting correlations between diversity of candidate genes and variation of bud burst in natural and segregating populations of European oaks. Heredity 2010, 104:438-448.

23. Gailing O, Langenfeld-Heyser R, Polle A, Finkeldey R: QTL loci affecting stomatal density and growth in a Quercus robur progeny: implications for the adaptation to changing environments. Glob Chang Biol 2008, 14:1934-1946

24. Parelle J, Zapater M, Scotti-Saintagne C, Kremer A, Jolivet Y, Dreyer E, Brendel O: Quantitative trait loci of tolerance to waterlogging in a European oak (Quercus robur L.): physiological relevance and temporal effect patterns. Plant Cell Environ 2007, 30(4):422-434.

25. Brendel $\mathrm{O}$, Le Thiec $\mathrm{D}$, Scotti-Saintagne C, Bodénès C, Kremer A, Guehl JM: Quantitative trait loci controlling water use efficiency and related traits in Quercus robur L. Tree Genet Genomes 2008, 4(2):263-278.

26. Barreneche T, Casasoli M, Russell K, Akkak A, Meddour H, Plomion C, Villani F, Kremer A: Comparative mapping between Quercus and Castanea using simple-sequence repeats (SSRs). Theor Appl Genet 2004, 108(3):558-566.

27. Casasoli M, Derory J, Morera-Dutrey C, Brendel O, Porth I, Guehl JM, Villani F, Kremer A: Comparison of Quantitative Trait Loci for Adaptive Traits Between Oak and Chestnut Based on an Expressed Sequence Tag Consensus Map. Genetics 2006, 172:533-546.

28. Casasoli M, Pot D, Plomion C, Monteverdi MC, Barreneche T, Lauteri M, Villani F: Identification of QTLs affecting adaptive traits in Castanea sativa Mill. Plant Cell Env 2004, 27(9):1088-1101.

29. Durand J, Bodénès $C$, Chancerel E, Frigerio JM, Vendramin G, Sebastiani F, Buonamici A, Gailing O, Koelewijn HP, Villani F, Mattioni C, Cherubini M, Goicoechea PG, Herrán A, Ikaran Z, Cabané C, Ueno S, Alberto F, Dumoulin PY, Guichoux E, de Daruvar A, Kremer A, Plomion C: A fast and costeffective approach to develop and map EST-SSR markers: oak as a case study. BMC Genomics 2010, 11:570-583.

30. Grattapaglia D, Sederoff R: Genetic linkage maps of Eucalyptus grandis and Eucalyptus urophylla using a pseudo-testcross: mapping strategy and RAPD markers. Genetics 1994, 137(4):1121-1137.

31. Berlin S, Lagercrantz U, von Arnold S, Öst T, Rönnberg-Wästljung AC: Highdensity linkage mapping and evolution of paralogs and orthologs in Salix and Populus. BMC Genomics 2010, 11:129-143.

32. McConnell M, Mamidi S, Lee R, Chikara S, Rossi M, Papa R, McClean P: Syntenic relationships among legumes revealed using a gene-based genetic linkage map of common bean (Phaseolus vulgaris L.). Theor Appl Genet 2010, 121(6):1103-1116.

33. Ueno $S$, Le Provost $G$, Léger V, Klopp C, Noirot C, Frigerio J-M, Salin F, Salse J, Abrouk M, Murat F, Brendel O, Derory J, Abadie P, Leger P, Cabane C, Barré A, de Daruvar A, Couloux A, Wincker P, Reviron M-P, Kremer A, Plomion C: Bioinformatic analysis of ESTs collected by Sanger and pyrosequencing methods for a keystone forest tree species: oak. BMC Genomics 2010, 11:650-674.

34. The Gene Ontology Consortium: Gene ontology: tool for the unification of biology. Nat Genet 2000, 25(1):x25-29.

35. Conesa A, Götz S, García-Gómez JM, Terol J, Talón M, Robles M: Blast2GO: a universal tool for annotation, visualization and analysis in functional genomics research. Bioinformatics 2005, 15(21(18)):3674-3680.

36. Shamir R, Maron-Katz A, Tanay A, Linhart C, Steinfeld I, Sharan R, Shiloh Y, Elkon R: EXPANDER an integrative program suite for microarray data analysis. BMC Bioinformatics 2005, 6:232-244. 
37. Dow BD, Ashley MV, Howe HF: Characterization of highly variable (GA/CT) $\mathrm{n}$ microsatellites in the bur oak, Quercus macrocarpa. Theor Appl Genet 1995, 91:137-141.

38. Isagi Y, Suhandono S: PCR primers amplifying microsatellite loci of Quercus myrsinifolia Blume and their conservation between oak species. Mol Ecol 1997, 6:897-899.

39. Steinkellner H, Fluch S, Turetschek E, Lexer C, Streiff R, Kremer A, Burg K, Glössl J: Identification and characterization of $(\mathrm{GA} / \mathrm{CT})_{n}$ - microsatellite loci from Quercus petraea. Plant Mol Biol 1997, 33(6):1093-1096.

40. Kampfer S, Lexer C, Glössl J, Steinkellner H: Characterization of (GA)n microsatellite loci from Quercus robur. Hereditas 1998, 129:183-186.

41. Lexer C, Heinze B, Steinkellner H, Kampfer S, Ziegenhagen B, Glosssl J: Microsatellite analysis of maternal half-sib families of Quercus robur, pedunculate oak: detection of seed contaminations and inference of the seed parents from the offspring. Theor Appl Genet 1999, 99:185-191

42. Aldrich PR, Michler CH, Weilin S, Romero-Severson J: Microsatellite markers for northern red oak (Fagaceae: Quercus rubra). Molecular Ecology Notes 2002, 2(4):472-474

43. Buck EJ, Hadonou M, James CJ, Blakesley D, Russell K: Isolation and characterization of polymorphic microsatellites in European chestnut (Castanea sativa Mill.). Mol. Ecol. Notes 2003, 3:239-241.

44. Marinoni D, Akkak A, Bounous G, Edwards KJ, Botta R: Development and characterization of microsatellite markers in Castanea sativa (Mill.). Mol. Breed 2003, 11:127-136.

45. Schuelke M: An economic method for the fluorescent labeling of PCR fragments. Nat Biotechnol 2000, 18(2):233-234.

46. Van Ooijen JW: JoinMap ${ }^{\circledR} 4$. In Software for the calculation of genetic linkage maps in experimental populations. Edited by Kyazma BV. Netherlands: Wageningen; 2006.

47. Voorrips RE: MapChart: Software for the graphical presentation of linkage maps and QTLs. J Hered 2002, 93(1):77-78.

48. Hulbert SH, Ilott TW, Legg EJ, Lincoln SE, Lander ES, Michelmore RW: Genetic analysis of the fungus, Bremia lactucae, using restriction fragment length polymorphisms. Genetics 1988, 120:947-958.

49. Chakravarti A, Lasher $L$, Reefer JE: A maximum likehood method for estimating genome length using genetic linkage data. Genetics 1991, 128:175-182.

50. Goudet J: FSTAT, a program to estimate and test gene diversities and fixation indices (version 2.9.3). 2001. Available from http://www.unil.ch/izea/ softwares/fstat.html. Updated from Goudet (1995).

51. Alberto F, Niort J, Derory J, Lepais O, Vitalis R, Galop D, Kremer A: Population differentiation of sessile oak at the altitudinal front of migration in the French Pyrenees. Mol Ecol 2010, 19(13):2626-2639.

52. Derory J, Leger P, Garcia V, Schaeffer J, Hauser MT, Salin F, Luschnig C, Plomion C, Glossl J, Kremer A: Transcriptome analysis of bud burst in sessile oak (Quercus petraea). New Phytol 2006, 170(4):723-738.

53. Lepoittevin C, Frigerio JM, Garnier-Géré P, Salin F, Cervera MT, Vornam B, Harvengt L, Plomion C: In vitro vs in silico detected SNPs for the development of a genotyping array: what can we learn from a nonmodel species? PLoS One 2010, 5(6):e11034.

54. Alberto FJ, Derory J, Boury C, Frigerio JM, Zimmermann NE, Kremer A: Imprints of natural selection along environmental gradients in phenology related genes of Quercus petraea. submitted.

55. Wegrzyn JL, Lee JM, Liechty J, Neale DB: PineSAP-sequence alignment and SNP identification pipeline. Bioinformatics 2009, 25(19):2609-2610.

56. Orita M, Iwahana $H$, Kanazawa $H$, Hayashi K, Sekiya T: Detection of polymorphisms of human DNA by gel electrophoresis as single-strand conformation polymorphism. Proc Natl Acad Sci USA 1989, 86:2766-2770.

57. Hsu TM, Chen X, Duan S, Miller RD, Kwok PY: Universal SNP genotyping assay with fluorescence polarization detection. Biotechniques 2001 31:560-570.

58. Plomion C, O'Malley DM: Recombination rate differences for pollen parents and seed parents in pine. Heredity 1996, 77:341-350.

59. Kumar S, Tamura K, Nei M: Mega3: integrated software for Molecular Evolutionary Genetics Analysis and sequence alignment. Brief Bioinform 2004, 5:150-163.

60. Gaut BS, Morton BR, McCaig BC, Clegg MT: Substitution rate comparisons between grasses and palms: Synonymous rate differences at the nuclear gene Adh parallel rate differences at the plastid gene rbcL. Proc Natl Acad Sci USA 1996, 93:10274-10279.
61. SanMiguel P, Gaut BS, Tikhonov A, Nakajima Y, Bennetzen JL: The paleontology of intergene retrotransposons of maize. Nat Genet 1998, 20:43-45.

62. Salse J, Abrouk M, Murat F, Masood Quraishi U, Feuillet C: Improved standards and new comparative genomics tools provide new insights into grasses paleogenomics. Briefings in Bioinf 2009, 10(6):619-630.

63. Salse J, Abrouk M, Bolot S, Guilhot N, Courcelle E, Faraut T, Waugh R, Close TJ, Messing J, Feuillet C: Reconstruction of monocotelydoneous protochromosomes reveals faster evolution in plants than in animals. PNAS USA 2009, 106:14908-14913.

64. Blanca J, Cañizares J, Roig C, Ziarsolo P, Nuez F, Pico B: Transcriptome characterization and high throughput SSRs and SNPs discovery in Curcubita pepo (Cucurbitaceae). BMC Genomics 2011, 12:104-119.

65. Qiu L, Yang C, Yang JB, Liu A: Exploiting EST databases for the development and characterization of EST-SSR markers in castor bean (Ricinus communis L.). BMC Plant Biol 2010, 10:278-288.

66. Yu Y, Daojun Yuan D, Liang S, Li X, Wang X, Lin Z, Zhang X: Genome structure of cotton revealed by a genome-wide SSR genetic map constructed from a $\mathrm{BC}_{1}$ population between Gossypium hirsutum and $G$. barbadense. BMC Genomics 2011, 12:15-29.

67. Sharma RK, Bhardwaj P, Negi R, Mohapatra T, Ahuja PS: Identification, characterization and utilization of unigene derived microsatellite markers in tea (Camellia sinensis L.). BMC Plant Biol 2009, 9:53-77.

68. Varshney RK, Graner A, Sorrells ME: Genic microsatellite markers in plants: features and applications. Trends Biotechnol 2005, 23(1):48-55.

69. Danan S, Veyrieras JB, Lefebvre V: Construction of a potato consensus map and QTL meta-analysis offer new insights into the genetic architecture of late blight resistance and plant maturity traits. BMC Plant Biol 2011, 11:16.

70. De Keyser E, Shu QY, Bockstaele EV, De Riek J: Multipoint-likelihood maximization mapping on 4 segregating populations to achieve an integrated framework map for QTL analysis in pot azalea (Rhododendron simsii hybrids). BMC Mol Biol 2010, 11:1-21.

71. Truntzler Barrière $Y$, Sawkins MC, Lespinasse D, Betran J, Charcosset A, Moreau L: Meta-analysis of QTL involved in silage quality of maize and comparison with the position of candidate genes. Theor Appl Genet 2010, 121(8):1465-1482.

72. Truco MJ, Antonise R, Lavelle D, Ochoa O, Kozik A, Witsenboer H, Fort SB, Jeuken MJW, Kesseli RV, Lindhout P, Michelmore RW, Peleman J: A highdensity, integrated genetic linkage map of lettuce (Lactuca spp.). Theor Appl Genet 2007, 115:735-746.

73. Blanc G, Charcosset A, Mangin B, Gallais A, Moreau L: Connected populations for detecting quantitative trait loci and testing for epistasis: an application in maize. Theor App/ Genet 2006, 113:206-224

74. Wu F, Tanksley SD: Chromosomal evolution in the plant family Solanaceae. BMC Genomics 2010, 11:182-193.

75. Vezzulli S, Troggio M, Coppola G, Jermakow A, Cartwright D, Zharkikh A, Stefanini M, Grando MS, Viola R, Adam-Blondon AF, Thomas M, This P, Velasco R: A reference integrated map for cultivated grapevine (Vitis vinifera L.) from three crosses, based on 283 SSR and 501 SNP-based markers. Theor Appl Genet 2008, 117:499-511.

76. Pelgas B, Bousquet J, Beauseigle $S$, Isabel N: A composite linkage map from two crosses for the species complex Picea mariana $\times$ Picea rubens and analysis of synteny with other Pinaceae. Theor Appl Genet 2005, 111:1466-1488.

77. Kremer A, Casasoli M, Barreneche T, Bodénès C, Sisco P, Kubisiak T, Scalfi M, Leonardi S, Bakker EG, Buiteveld J, Romero-Severson J, Arumuganathan K, Derory J, Scotti-Saintagne C, Roussel G, Bertocchi ME, Lexer C, Porth I, Hebard F, Clark C, Carlson J, Plomion C, Koelewijn H, Villani F: Fagaceae trees. In Genome Mapping \& Molecular Breeding. Forest Trees. Edited by Kole CR. Heidelberg, New York, Tokyo: Springer-Verlag, Berlin; 2007:16-187. 5.

78. N'Diaye A, Van de Weg WE, Kodde LP, Koller B, Dunemann F, Thiermann M, Tartarini S, Gennari F, Durel CE: Construction of an integrated consensus map of the apple genome based on four mapping populations. Tree Genet Genomes 2008, 4:727-743.

79. Doligez A, Adam-Blondon AF, Cipriani G, Di Gaspero G, Laucou V, Merdinoglu D, Meredith CP, Riaz S, Roux SC, This P: An integrated SSR map of grapevine based on five mapping populations. Theor Appl Genet 2006, 113(3):369-382.

80. Saintagne $C$, Bodénès $C$, Barreneche $T$, Pot D, Plomion C, Kremer A: Distribution of genomic regions differentiating oak species assessed by QTL detection. Heredity 2004, 92(1):20-30. 
81. Abadie P, Roussel G, Dencausse B, Bonnet C, Bertocchi E, Louvet JM, Kremer A, Garnier-Géré P: Strength, diversity and plasticity of postmating reproductive barriers between two hybridizing oak species (Quercus robur L. and Quercus petraea (Matt) Liebl.). J Evol Biol 2011, 25:157-173.

82. Manos PS, Z-K Zhou ZK, Cannon CH: Systematics of Fagaceae: phylogenetic tests of reproductive trait evolution. International Journal of Plant Sciences 2001, 162:1361-1379.

83. Jaillon O, Jean-Marc Aury JM, Noel B, Policriti A, Clepet C, et al: The grapevine genome sequence suggests ancestral hexaploidization in major angiosperm phyla. Nature 2007, 449:463-467.

84. Salse J: In silico archeogenomics unveils modern plant genome organisation, regulation and evolution. Curr Opin Plant Biol 2012, 15:1-9.

85. Faivre-Rampant P, Lesur I, Boussardon C, Bitton F, Martin-Magniette ML, Bodénès C, Le Provost $G$, Berges H, Fluch S, Kremer A, Plomion C: Analysis of $B A C$ end sequences in oak, a keystone forest tree species, providing insight into the composition of its genome. BMC Genomics 2011, 12:292-305.

doi:10.1186/1471-2229-12-153

Cite this article as: Bodénès et al: Comparative mapping in the Fagaceae and beyond with EST-SSRs. BMC Plant Biology 2012 12:153.

\section{Submit your next manuscript to BioMed Central and take full advantage of:}

- Convenient online submission

- Thorough peer review

- No space constraints or color figure charges

- Immediate publication on acceptance

- Inclusion in PubMed, CAS, Scopus and Google Scholar

- Research which is freely available for redistribution 